\title{
REACTOR VESSEL CLADDING SEPARATE EFFECTS STUDIES*
}

W. R. Corwin

Metals and Ceramics Division OAK RIDGE NATIONAL LABORATORY Oak Ridge, Tennessee 37831

\author{
CONF-8510173-6 \\ TI86 002199
}

\section{SUMMARY}

The existence of a layer of tough weld overlay cladding on the interior of a light-water reactor pressure vessel could mitigate damage caused during certain overcooling transients. The potential benefit of the cladding is that it could keep a short surface flaw, which would otherwise become long, from growing either by impeding crack initiation or by arresting a running crack. Two aspects critical to cladding behavior will be reported: 1rradiation effects on cladding toughness and the response of mechanically loaded, flawed structures in the presence of cladding.

A two-phase 1rradiation experiment is being conducted. In the first phase, Charpy impact and tensile specimens from a sing1e wire, submerged-arc stainless steel weld overlay were irradiated to $2 \times 10^{23}$ neutrons $/ \mathrm{m}^{2}(>1 \mathrm{MeV})$ at $288^{\circ} \mathrm{C}$. Typical, good quality pressure vessel cladding, exhibited very

${ }^{*}$ Research sponsored by the office of Nuclear Regulatory Research, U.S. Nuclear Regulatory Commission, under Interagency Agreements DOE 40-551-7.5 and 40-552-75 with the U.S. Department of Energy under contract DE-AC05-840R21400 with Martin Marietta Energy Systems, Inc.

\section{DISCLAIMER}

This report was propared as an account of work sponsored by an agency of the United States Government. Neither the United States Government nor any agency thereof, nor any of their omployees, makes any warranty, express or implied, or assumes any legal liability of responsibility for the accuracy, completeness, or usefulness of any information, apparatus, product, or process disclosed, or represents that its use would not infringe privately owned rights. Reference herein to any spocific commercial product, procese, or service by trade name, trademark, manufacturer, or otherwise does not necessarily constitute or imply its endorsement, recom. mendation, or favoring by the United States Government or any apency thereof. The vietrs and opinions of authoss expresed herein do not necessarily state or reflect those of the United Stated Government or any agency thereor.
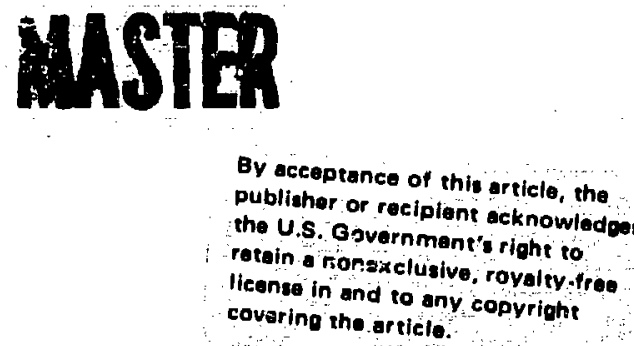
little irradiation-induced degradation. However, ductile-to-brittle transition behavior, caused by temperature-dependent failure of the residual $\delta$-ferrite, was observed... In contrast, specimens from a highly diluted, poor quality weldment were markeoly embrittled. In the second phase of Irradiations, now in progress, a commercially produced three-wire series-arc weldment will be evaluated under Identical Irradiation and testing conditions as the first series. In addition, $0.5 \mathrm{~T}$ compact specimens of both weldments and higher fluences will be examined.

A two-phase program is also being conducted utilizing relatively large bend specimens that have been clad and flawed on the tenston surface. The testing rationale is that if a surface flaw is pinned by the cladding and cannot grow longer, it will also not grow beyond a certain depth, thereby arresting the entire flaw in a stress field in which it would otherwise propagate through the specimen. The results of phase one showed that single wire cladding with low-to-moderate toughness appeared to have a limited ability to mitigate crack propagation. For the second phase, three-wire cladding has been deposited on a base plate with a very high ductile-to-brittle transition temperature allowing testing to ascertain the crack-inhibiting capability of tough upper shelf claddling. 


\section{INTRODUCTION}

It has been proposed that the existence of a layer of tough weld overlay cladding on the interior of a light-water reactor (LWR) pressure vessel could mitigate damage caused during certain overcooling transients. The potential benefit of the cladding is that it could keep a short surface flaw, which would otherwise become long, from growing either by impeding crack initiation or by arresting a running crack. If this can indeed be proven, the 1mplications for existing LWR's, particularly those with substantial reactor pressure vessel (RPV) embrittlement, would be significant. It would contribute to useable vessel lifetimes teyond the current screening criteria if used in $a$ plant specific analysis. Moreover, if consideration of cladding benefit resulted in reducing the flaw size or density distributions currently being assuned, a reduction would result in the cumulative fallure probability calculated using probabilistic risk assessment methodologies.

To assess the potential benefits of cladding, at least. two areas must be addressed, (1) the residual toughness of cladding following 1rradiation typical of LWR service, and (2) the mechanical effect cladding would have on a structure when loaded under conditions relevant to a postulated accident. The Heavy Section Steel Technology (HSST) program has established two phase research efforts in both of these areas. The first phase in both areas has been completed. A laboratory submerged arc overlay weldment has been examined for both its radiation response and its structural effects on a laboratory. engineering structure, a clad plate loaded in bending. These results have been reported separately before 1,2 and will be summarized here. In the second phase, which will also be described, similar experiments are being conducted using a commerclally procured three-wire series arc weld overlay, typical of cladding applications in the production of early RPV's. 


\section{TEST MATERIALS - PHASE ONE}

The specimens for both programs were taken from laboratory weldments fabricated by the automated single-wire oscillating submerged arc procedure. The weldments consisted of a lower layer of type 309 stainless steel deposited on A 533 grade B class 1 plate, followed by one or two layers of type 308 stalnless steel cladding. 1 The weldments were post weld heat treated (PWHT) at $621^{\circ} \mathrm{C}$ for $40 \mathrm{~h}$, typical of commerclal practlce. Three layers of cladding were required to provide adequate thickness from which to remove irradiation test specimens. The beam specimens recelved only two layers of cladding. The multilayer production of cladding contrasts with typical commercial U.S. practice, In which a single layer of overlay approximately $5 \mathrm{~mm}$ thick is applied by efther multiple wire or strip-cladding submerged arc procedures. The material compositions of each layer of weld metal are given in Table 1 .

Table 1. Chemical composition of overlay weldments

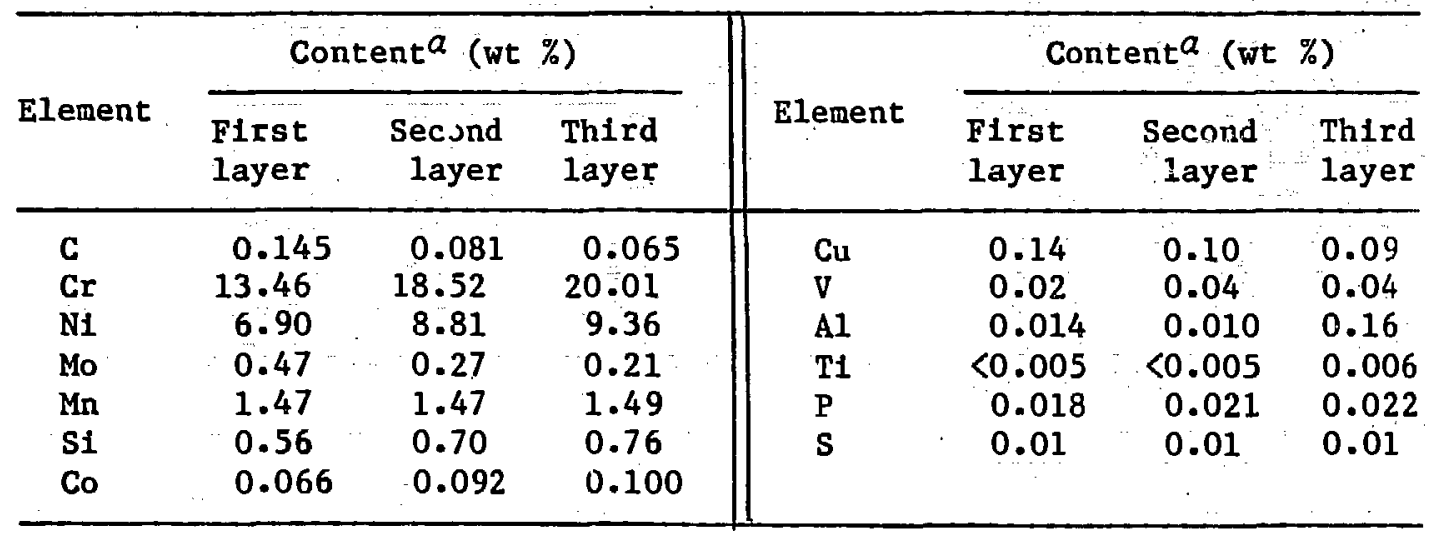

$a_{\mathrm{Balance}} \mathrm{Fe}$; with $\mathrm{Nb},<0.01 ; \mathrm{Ta},<0.01 ; \mathrm{As},<0.03$; and $\mathrm{B}$; <0.001 for all layers. 
Metallographic examination of the cladding showed that the third layer appeared typical of LWR stainless steel overlay, whereas the first layer had incurred excessive dilution as a result of base metal melting during welding. Photomicrographs of the three layers illustrate the radically different microstructures in the finished weldment. The third (upper) pass (Fig. 1) shows a distributj $\mathrm{n}$ of $\delta$-ferrite in an austenite matrix quite typical of microstructures seen in good practice commerclal weld overlay cladding of reactor pressure vessels. 2 The effect of the 40-h PWHT on these materials is to partially transform the $\delta$-ferrite to sigma phase, as well as precipitate some carbides.

The first and second layers of cladding, on the other hand, formed atypical microstructures as a result of the excessive dilution (approximately $50 \%$ ) by the base metal and first pass weldment, respectively. Amounts of dilution in good practice cladding are typlcally in the range of 10 to $25 \%$. The second layer (Fig. 2) contains $\delta$-ferrite dispersed in austentte but in addition contains limited regions in which martensite is also present. Subsequent examination of the fracture mecharism indicated that the martensite in the second layer did not appreclably affect its properties, such that it be induced very much like the third layer. The first layer had sufficient dilution to move it entirely from the $\delta$-ferrite-forming regton of the Schaeffler diagram $^{3}$ and into the austenite-plus-martensite region (these are the dominant phases and notably affect its fracture properties). Examination of its mfcrostructure (FIg. 3), however, shows three distinct regions. The use of the ferrofluid magnetic etching technique 4 and studies in the transmission electron microscope verified the lightest regions to be austenite, the light gray regions tempered martensite, and the dark regions $\delta$-ferrite decorated with $\mathrm{M}_{23} \mathrm{C}_{6}$ type carbides. 
Figures 1 and 2 go here.

Fig. 1. The microstructure of the third layer of type 308 stainless steel weld overlay is typical of reactor pressure vessel cladding with $\delta$-ferrite in an austentte matrix.

Fig. 2. The second layer of the overlay (type 308 stainless steel) includes patches of martensite (11ght gray) in addition to the $\delta$-ferrite in an austenite matrix. 


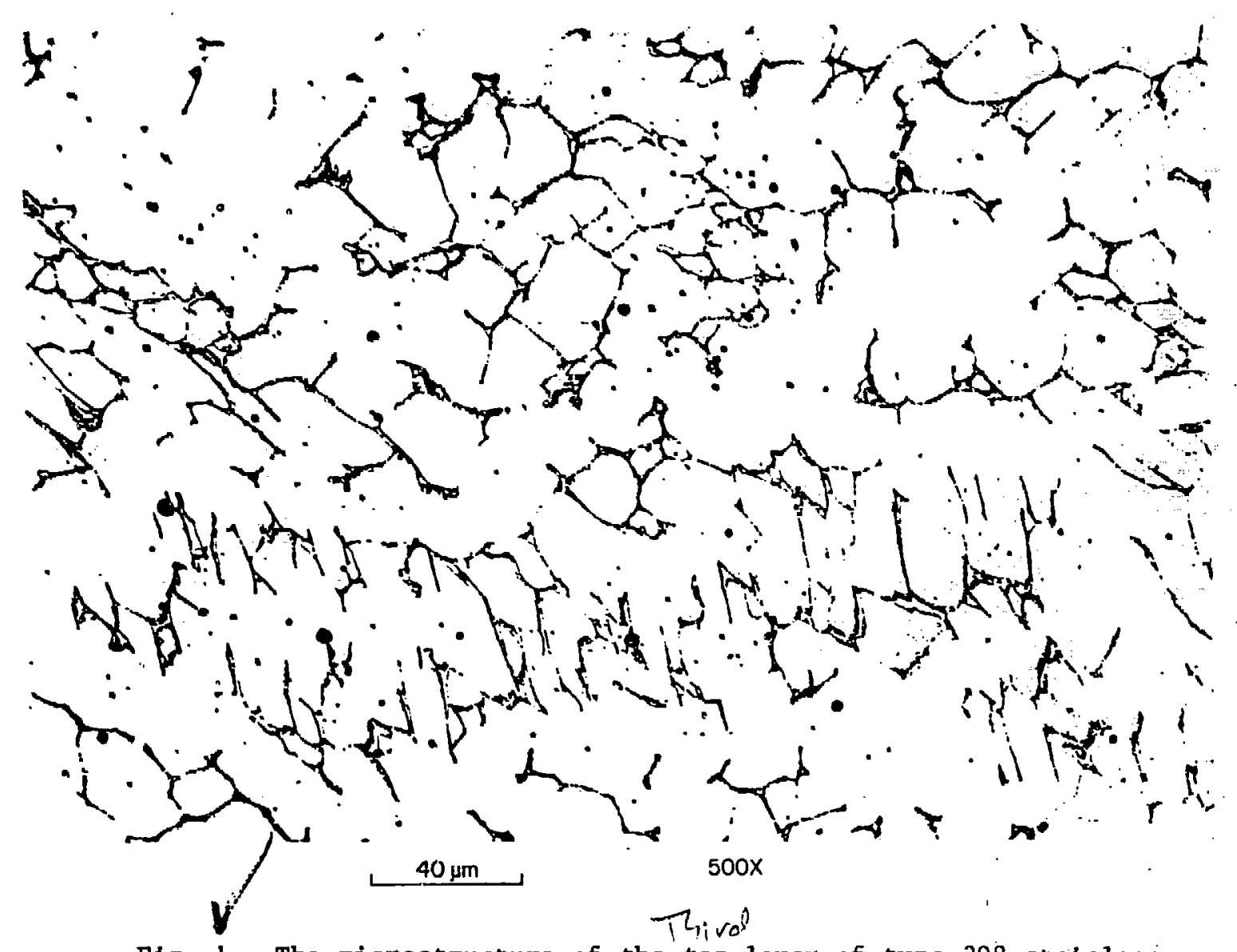

Fig. 1. The microstructure of the layer of type 308 stainless steel weld overlay is typical of reactor pressure vessel cladding with o-ferrite in an austenite matrix. 


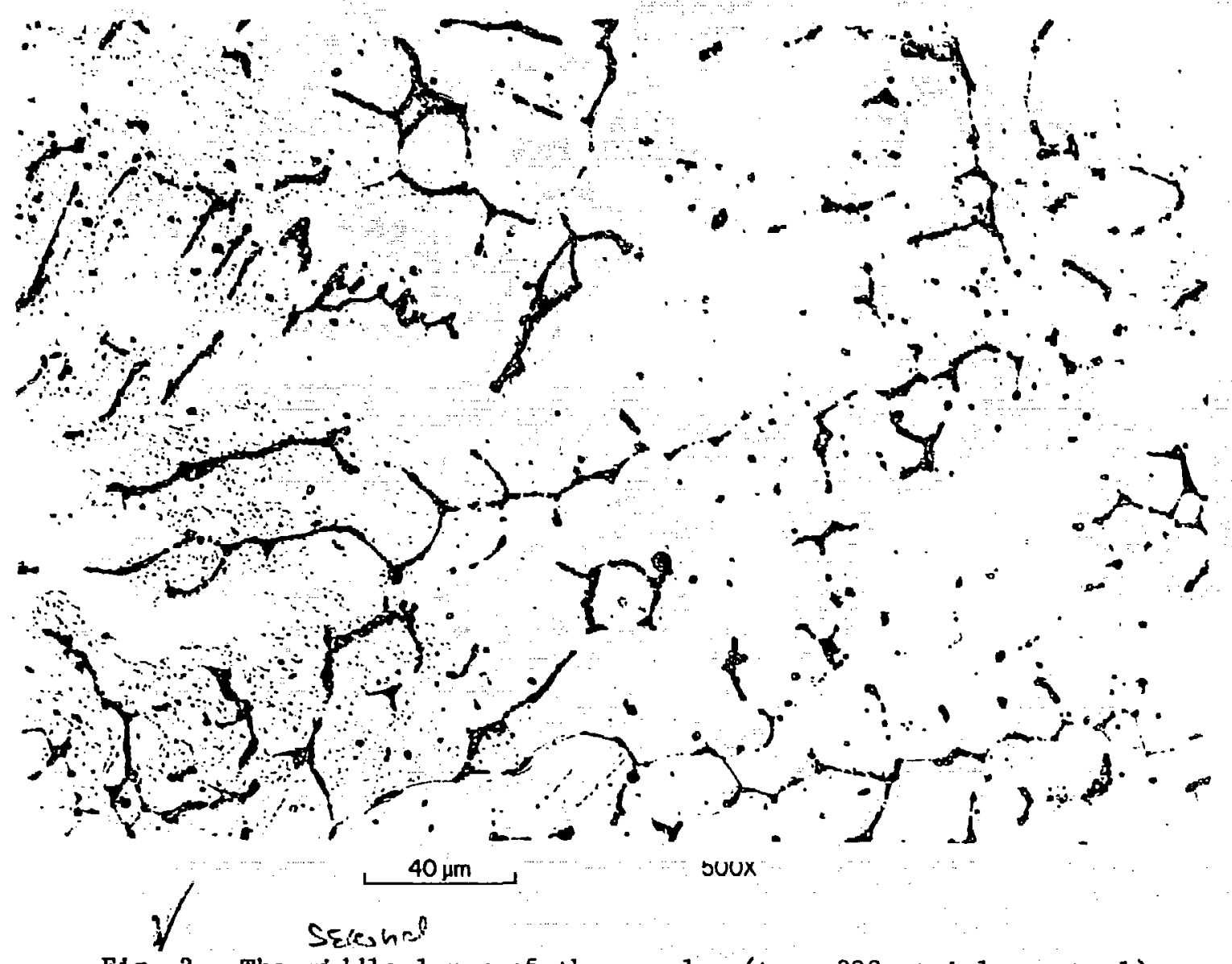

Fig. 2. The layer of the overlay (type 308 stainless steel) includes patches of martensite (light gray) In addition to the $\delta$-ferrite in an austenite matrix. 
F1g. 3. The high base metal dilution of the first (lowest) layer of cladding, type 309 stainless steel, resulted in a three-phase microstructure of austenite (11ghtest region), martensite (11ght gray), and $\delta$-ferrite decorated with additional carbides (black).

Although the investigation of high-dilution cladding was not the initial aim of the cladding studies, it may well be highly germane to the question of the effects of cladding on RPV integrity. High base metal dilution of cladding, caused by Inadequate control of welding procedures, and the resulting microstructures have been documented 5,6 in commercial RPVs. Typlcally, the resulting material has poorer mechanical and/or corrosion 


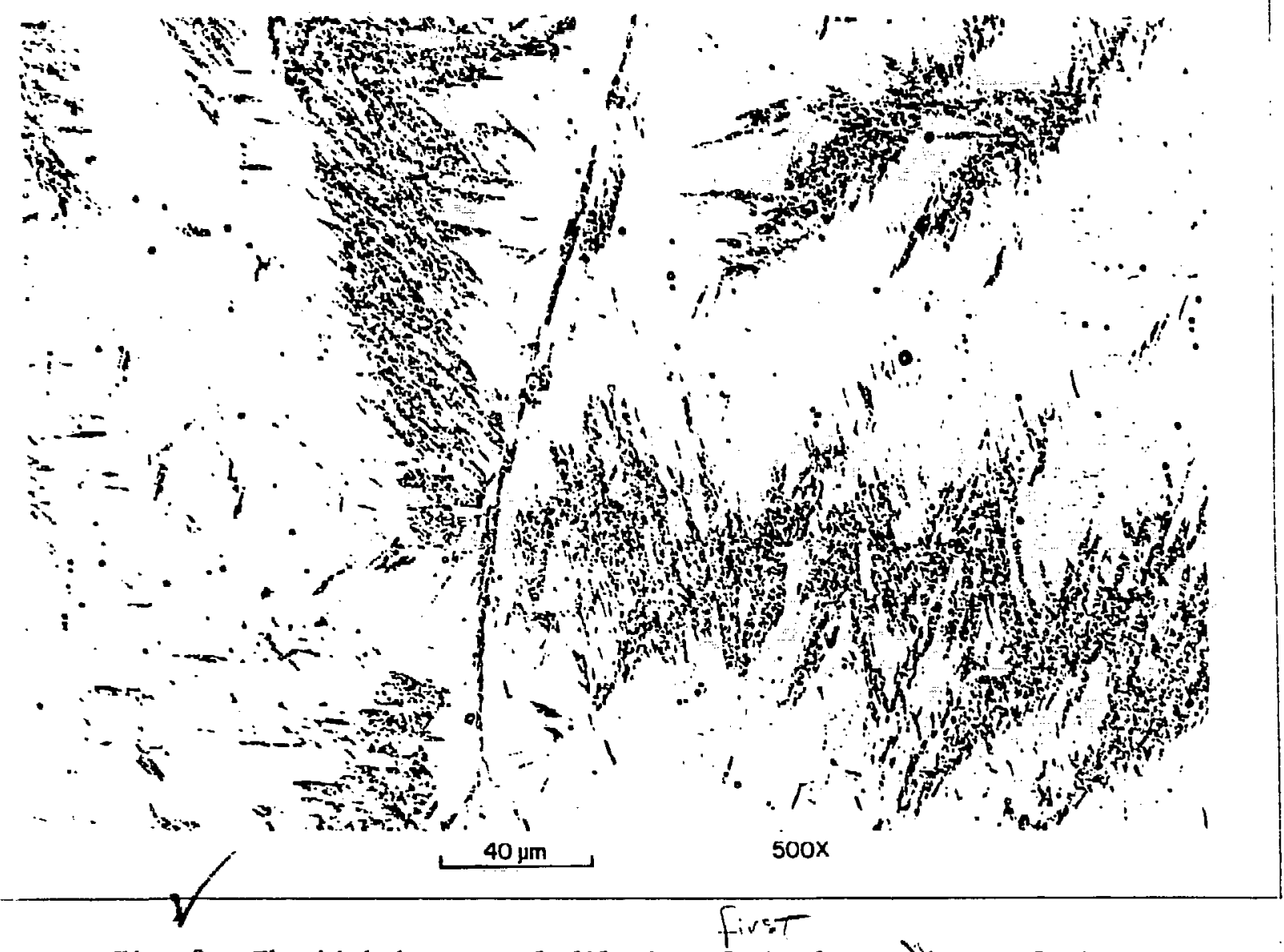

Fig. 3. The high base metal dilution of the lowest) layer of cladding, type 309 stainless stee1, resulted in a three-phase microstructure of austenite (11ghtest region), martensite (light gray), and s-ferrite decorated with additional carbides (black). 
properties in the unirradiated condition; no information has been previously available on the irradiation damage of such material. Its inclusion has provided insight into the behavior of substandard weld overlay cladding possibly representative of irradiated material actually in the fleld.

\section{EFFECTS OF IRRADIATION}

EXPERINENTAL DETAILS - PHASE ONE

To examine the effects of Irradiation on the different microstructures,

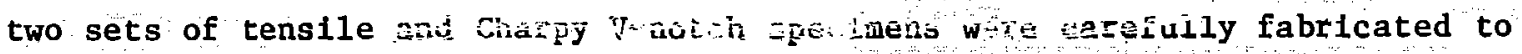
be contained as fully as possible within elther the upper two layers (nominally type 308 specimens) or the lower layer (nominally type 309 specimens) (FIg. 4). All specimens were fabricated with the specimen axis parallel to the welding direction. The Charpy specimens were notched on the surface parallel to and nearer the base metal in all cases.

The nominally type 308 specimens consistently had ferrite numbers of 2 to 6 (corresponding roughly to percentages of ferrite), as did the portion of nominally type 309 specimens composed of upper weld pass layers. The notched side of the nominally type 309 specimens closest to the base metal interface exhibited ferrite numbers up to and in excess of 30 (off scale). 0ptical examination of the microstructure of the type 309 layer fndicates the amounts of martensite and ferrite to be 30 to $45 \%$ and 10 to $15 \%$, respectively.

Fig. 4. Location of the Charpy specimens nominally called type 308 and 309. 
ORNL.DWG 84-1907
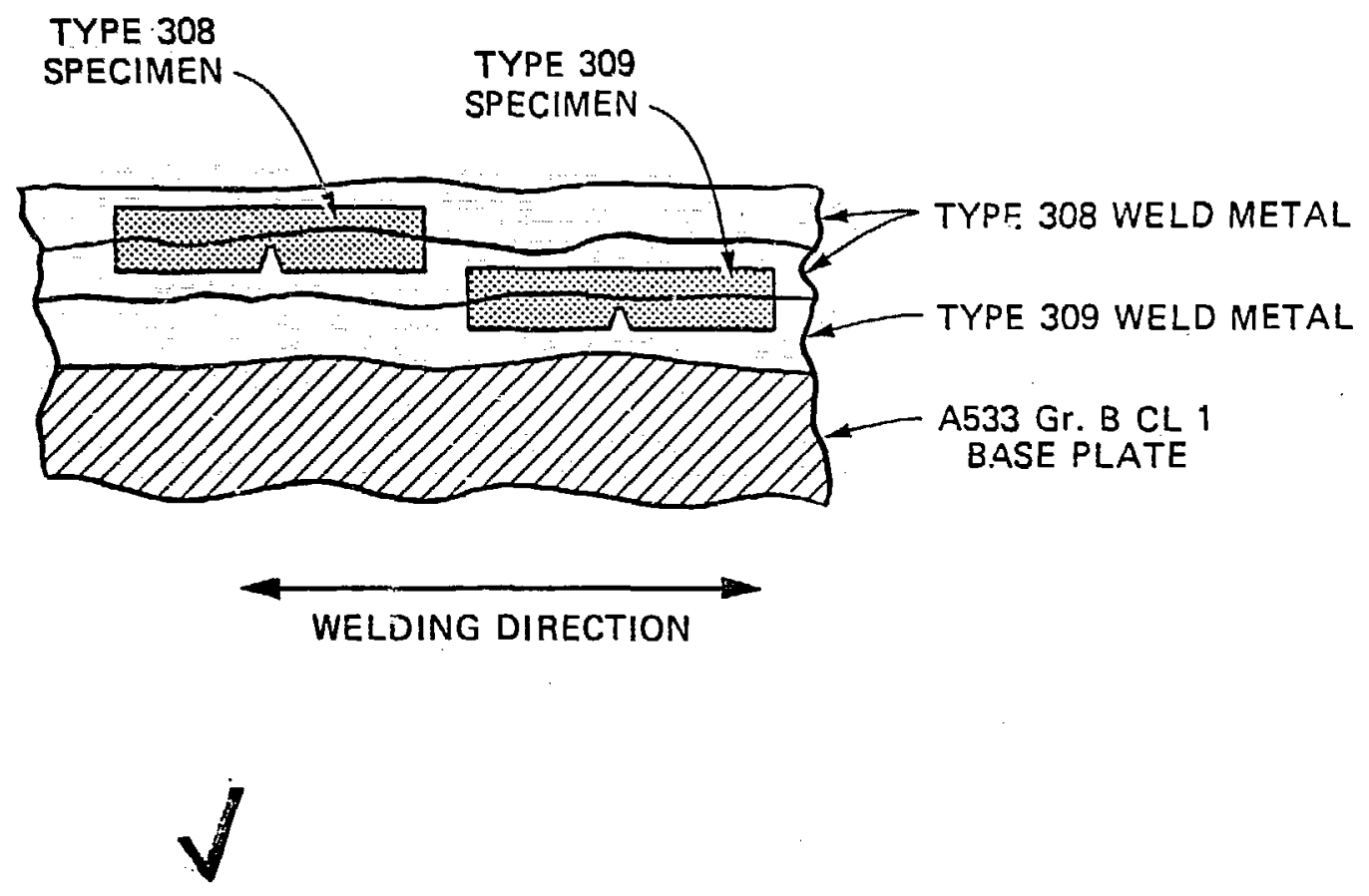

Fig. 4. Location of the Charpy specimens nominally called type 308 and 309 . 
IRRADIA'ION HISTORY - PHASE ONE

The specimens were irradiated in the core of the 2-MW pool reactor (UBR) at the Nuclear Sclence and Technology Facility, Buffalo, New York. Two separate capsules were used, one each for the types 308 and 309 stainless steel specimens. The capsules were instrumented with thermocouples and dosimeters and were rotated $180^{\circ}$ once during the irradiation for fluence balancing. The capsules containing the type 303 and 309 specimens reached average fluences of $2.09 \times 10^{23}$ neutrons $/ \mathrm{m}^{2}(>1 \mathrm{MeV}) \pm 10 \%$ during $679 \mathrm{~h}$.of irradiation and $2.02 \times 10^{23}$ neutrons $/ \mathrm{m}^{2}(>1 \mathrm{MeV}) \pm 5 \%$ in $508 \mathrm{~h}$, respectively. The fluences are for a calcuịated spectrum based on $\mathrm{Fe}, \mathrm{N} 1$, and Co dosimet:ry wires. Temperatures were maintained at $288 \pm 14^{\circ} \mathrm{C}$ except for the Inftial week of irradiation, when measurements as 10 as $263^{\circ} \mathrm{C}$ were recorded.

RESULTS AND DISCUSSIONS - PHASE ONE

Tensile testing was conducted at room temperature, $149^{\circ} \mathrm{C}$, and $288^{\circ} \mathrm{C}$. Irradiation increased the yield strength of the type 309 specimens by 30 to $40 \%$, whereas the increase of the type 308 specimens was only 5 to $25 \%$. Surprisingly, the total elongation and reduction of area of both materials increased during irradiation (Tabie 2).

The effect of irradiation on the Charpy impact properties of the type 308 weld metal representative of typical weld overlay cladding was relatively sma11 (Fig. 5). Only a very slight upward shift in transition temperature $\left(15^{\circ} \mathrm{C}\right)$ and drop in upper shelf $(<10 \%)$ were observed. Both the control and irradiated Charpy specimens exhibited curves more typical of ferritic materials than of austenitic stainless steel with respect to the abrupt transition from htgh- to low-energy fracture. Scanning electron microscopy (SEM) of unirradiated specimens tested in the lower transition and upper-shelf 
Table 2, Tensile properties of stalnless steel cladding before and after irradiation at $288 \pm 14^{\circ} \mathrm{C}$

\begin{tabular}{|c|c|c|c|c|c|c|c|}
\hline \multirow{2}{*}{ Specimen } & \multirow{2}{*}{$\begin{array}{l}\text { Material } \\
\text { type }\end{array}$} & \multirow{2}{*}{$\begin{array}{c}\text { Fluence, } \\
>1 \mathrm{MeV} \\
\text { (neutrons } / \mathrm{m}^{2} \text { ) }\end{array}$} & \multirow{2}{*}{$\begin{array}{c}\text { Test } \\
\text { temperature } \\
\left({ }^{\circ} \mathrm{C}\right)\end{array}$} & \multicolumn{2}{|c|}{ Strength (MPa) } & \multirow{2}{*}{$\underset{\substack{\text { Total } \\
\text { elongation }}}{b}$} & \multirow{2}{*}{$\begin{array}{c}\text { Reduction } \\
\text { of area } \\
(\%)\end{array}$} \\
\hline & & & & Yield & U1timate & & \\
\hline $\begin{array}{l}\text { CPL-80 } \\
\text { CPL-83 }\end{array}$ & $\begin{array}{l}309 \\
309\end{array}$ & $\begin{array}{l}0 \\
0\end{array}$ & $\begin{array}{l}27 \\
27\end{array}$ & $\begin{array}{l}299 \\
273\end{array}$ & $\begin{array}{l}593 \\
586\end{array}$ & $\begin{array}{l}28.4 \\
49.5\end{array}$ & $\begin{array}{l}30.6 \\
55.5\end{array}$ \\
\hline $\mathrm{CPC}-72$ & 308 & 0 & 27 & 268 & 589 & 40.0 & 55.0 \\
\hline $\mathrm{CPC}-73$ & 308 & 0 & 27 & 276 & 568 & 42.4 & 58.0 \\
\hline$C P L-81$ & 309 & $2.0 \times 10^{23}$ & 29 & 388 & 606 & 39.4 & 48.0 \\
\hline CPL--85 & 309 & 2.0 & 29 & 364 & 624 & 45.4 & 58.0 \\
\hline $\mathrm{CPC}-70$ & 308 & 2.1 & 29 & 289 & 605 & $51.5^{\circ}$ & 62.3 \\
\hline $\mathrm{CPC}-75$ & 308 & 2.1 & 29 & 300 & 589 & 60.1 & 67.1 \\
\hline CPL-86 & 309 & 0 & 149 & 213 & 448 & 31.9 & 55.5 \\
\hline CPL-89 & 309 & 0 & 149 & 236 & 450 & 30.4 & 63.4 \\
\hline $\mathrm{CPC}-77$ & 308 & 0 & 149 & 221 & 445 & 31.3 & 44.0 \\
\hline $\mathrm{CPC}-78$ & 308 & 0 & 149 & 213 & 444 & 32.4 & 52.0 \\
\hline CPL -82 & 309 & 2.0 & 149 & 297 & .508 & $57_{1.2} 2$ & 57.9 \\
\hline CPL -87 & 309 & $2 \cdot 0$ & 149 & 345 & 526 & 48.6 & 60.4 \\
\hline $\mathrm{CPC}-71$ & 308 & 2.1 & 149 & 290 & 501 & 56.3 & 59.3 \\
\hline $\mathrm{CPC}-76$ & 308 & 2.1 & 149 & 262 & 485 & 53.8 & 58.1 \\
\hline$C P L=90$ & 309 & 0 & 288 & 195 & 429 & 31.7 & 51.5 \\
\hline CPL-91 & 309 & 0 & 288 & 207 & 423 & 32.4 & 52.2 \\
\hline CPC-79 & 308 & 0 & 288 & 205 & 393 & 28.5 & 51.4 \\
\hline $\mathrm{CPC}-80$ & 308 & 0 & 288 & 205 & 402 & $27: 6$ & 53.3 \\
\hline CPL $=84$ & 309 & 2.0 & 288 & 277 & 475 & 52.9 & 56.6 \\
\hline $\begin{array}{l}\text { CPL-88 } \\
\text { CPC-74 }\end{array}$ & $\begin{array}{l}309 \\
308\end{array}$ & $\begin{array}{l}2.0 \\
2.1\end{array}$ & $\begin{array}{l}288 \\
288\end{array}$ & $\begin{array}{l}290 \\
198\end{array}$ & $\begin{array}{l}501 \\
422\end{array}$ & $\begin{array}{l}56.3 \\
51.9\end{array}$ & $\begin{array}{l}59.3 \\
55.0\end{array}$ \\
\hline CPC-81 & 308 & 2.1 & 288 & 232 & 427 & 49.5 & 59.8 \\
\hline
\end{tabular}

aype 309 consists primarily of the first metal pass, type 308 primarily the third (last pass).

$b_{\text {Gage length/diameter }}=7$. 
Fig. 5. Effect of irradiation on the Charpy impact energy of type 308 stainless steel cladding.

regions clearly show the transition from a cleavage or quasi cleavage to a flbrous fracture mode ${ }^{1}$ for all types of cladding. This behavior compares well with the work of other researchers, ${ }^{7-9}$ who have shown that fully ductile fracture occurs in as-welded austenitic weld metal as low as $4 \mathrm{~K}$ but that quasi cleavage can occur in weld metal that has received a PWHT in the temperature range in which carbide precipitation and sigma formation occur.

The interpretation of the impact results of the nominaliy type 309 specimens is more complicated. Since the type 309 weld pass was not thick enough to obtain specimens composed entirely of type 309 weld metal, a portion of all the specimens nominally called type 309 is indeed type 308 . Optical and scanning electron microscopy revealed that the transition temperature for the highly diluted type 309 stainless steel was appreciably lower than that of the type 308.1 

As a result, Interpreting the nomfinally type 309 specimen Charpy Impact curves demands that the dual fracture properties of the type 308 and 309 portions of the material be taken into consideration. The impact data falls into a bimodal population related to the amount of the tougher type 308 weld metal present in the sample. The more type 308 in the specimen, the lower the apparent transition temperature of the specimen. By using the percentage of type 308 weld metal measured visually on each fracture surface as a criterion, the impact data were divided into low- and high-energy populations. These populations were arbitrarily chosen to contain less than 70 and $80 \%$ type 308 weld metal for the unirradiated and irradiated data sets, respectively. (FIgs. 6 and 7), because these produced the most distinct difference between the data sets.

Once these populations within the type 309 data were established, the effect of Irradiation was seen to be quite appreciable (Fig. 8). Both populations experienced large drops In upper-shelf energy of up to $50 \%$ and shifts in transition temperature of up to $100^{\circ} \mathrm{C}$.

Fig. 6. Charpy impact energy of the unirradiated nominally type 309 stainless steel cladding divided into low-and high-energy populations based on the fraction of type 308 weld metal in the specimen ligament. 

Figures 7 and 8 go here.

Fig. 7. Charpy Impact energy of the Irradiated nominally type 309 stainless steel cladding divided into low- and high-energy populations based on the fraction of type 308 weld metal in the specimen 11gament.

F1g. 8. Effect of Irradiation on the Charpy Impact energy of high- and low-energy populations of the specimens of nominal type 309 cladding. 



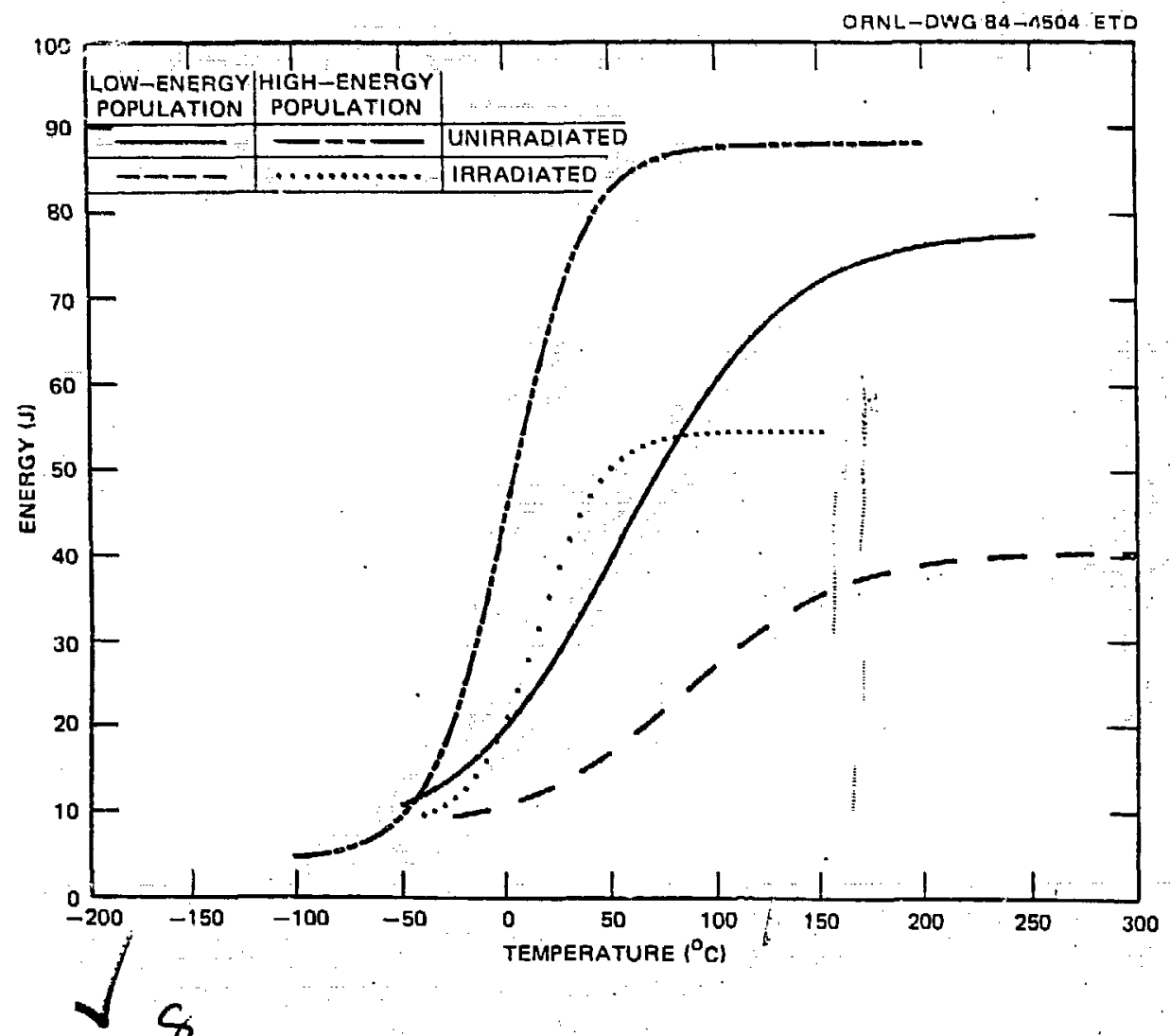

S.

Fig. 17. Effect of 1rradiation on the Charpy impact energy of highand low-energy populations of the specimens of nominal type 309 cladding. 
The extensive toughness degradation seen in the type 309 material as compared with very little in the type 308 is probably due to the higher fraction of ferritic phases in the type 309 resulting from the excessive base metal dilution and their intrinsically higher radiation sensitivity.

To investigate the cause of the ductile to brittle transition behavior, a study of the fracture path within both the type 308 and 309 weld metal was undertaken. Unirradiated Charpy specimens were metallographically prepared such that the central plane of the specimen perpendicular to the fracture face was visible, providing an "edge-on" view of the fracture profile. Two specimens are examined here, one tested at $-30^{\circ} \mathrm{C}$ low in the transition, and another tested at $50^{\circ} \mathrm{C}$ near the upper knee of the transition. Both specimens contain both type 309 and 308 layers of cladding.

Low in the transition, the fracture path in the type 309 (Fig. 9) follows the ferrite (dark phase) in the structure. Note that the martensite and austenite are not differentiated by the etching technique used here. As the fracture progresses into the type 308 (Fig. 10), the fracture path remains within the $\delta$-ferrite islands. Clearly, in both materials the fracture is dominated by the ferritic phases at the lower temperature.

However, examining the fracture path in the type 309 stainless tested. near the knee of the upper shelf (Fig. 11) shows that preferential fracture of the ferrite does not occur at this high temperature. Similarly, the fracture profile within the type 308 stainless steel (Fig. 12) shows clear indications of a dimple rupture fallure mode with no preferential $\delta$-ferrite failure.

Therefore, based on the fractographic evidence; it is assumed that for both the types 308 and 309 stainless steel cladding at upper-shelf temperatures the ferrite is at least as tough as the austenite such that the 
Figures 9 and 10 go on a page.

Fig. 9. The low temperature fracture path in type 309 cladding shown following patches of ferrite.

Fig. 10. The low temperature fracture path of type 308 cladding shown following $\delta$-ferrite islands.

Figures 11 and 12 go on a page.

Fig. 11. The profile of the fracture path of type 309 stainless steei shows that the fracture does not preferentially follow the ferrite (gray patches), as opposed to the matrix of the austenite at higher temperatures.

Fig. 12. The profile of the fracture path of type 308 stainless steel shows that the fracture does not preferentially follow the $\delta$-ferrite (gray patches) at higher temperatures 



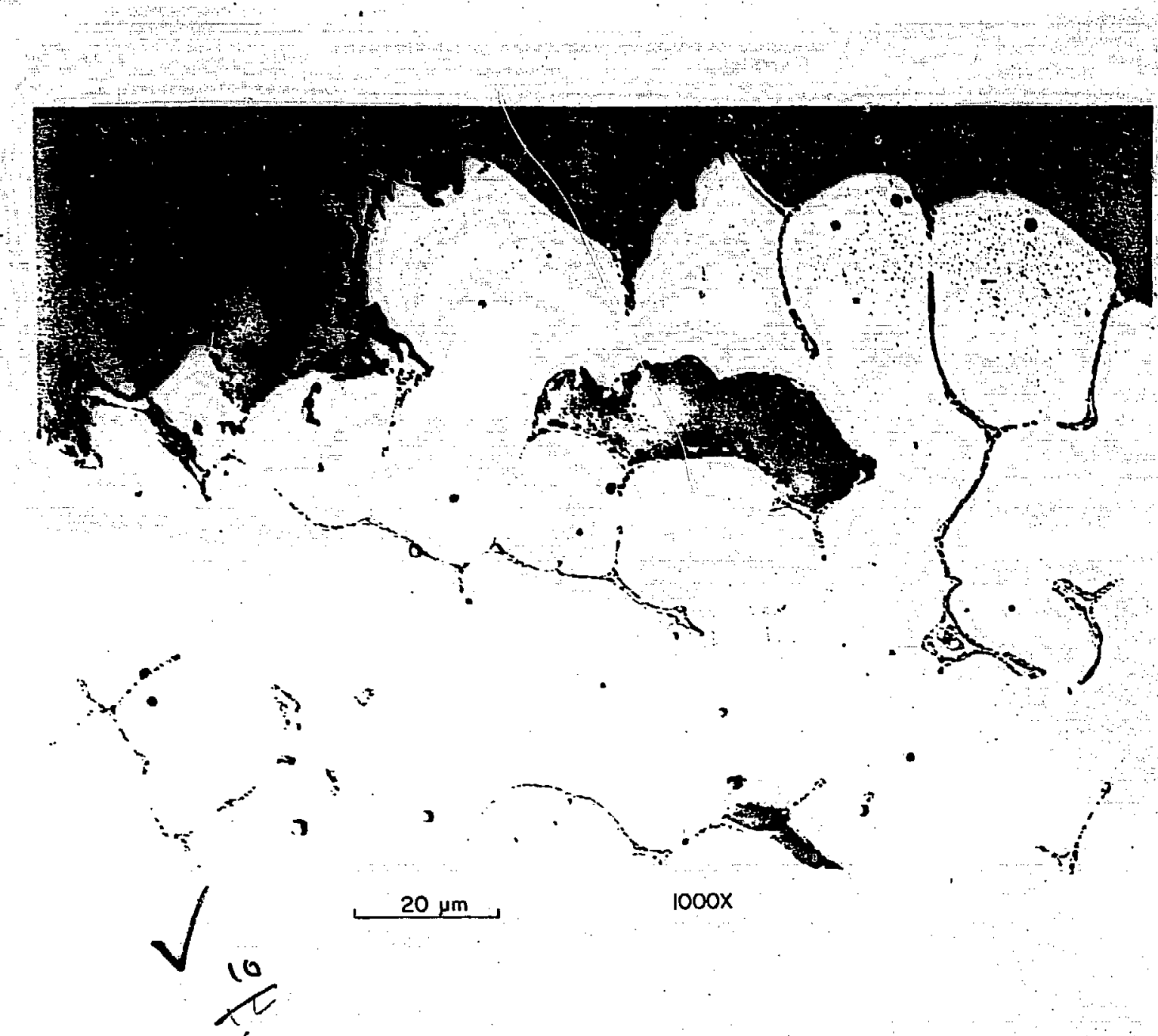

Fig. 21. Detail of location 3 in Fig. 18 showing fracture path following $\delta$-ferrite islands. 


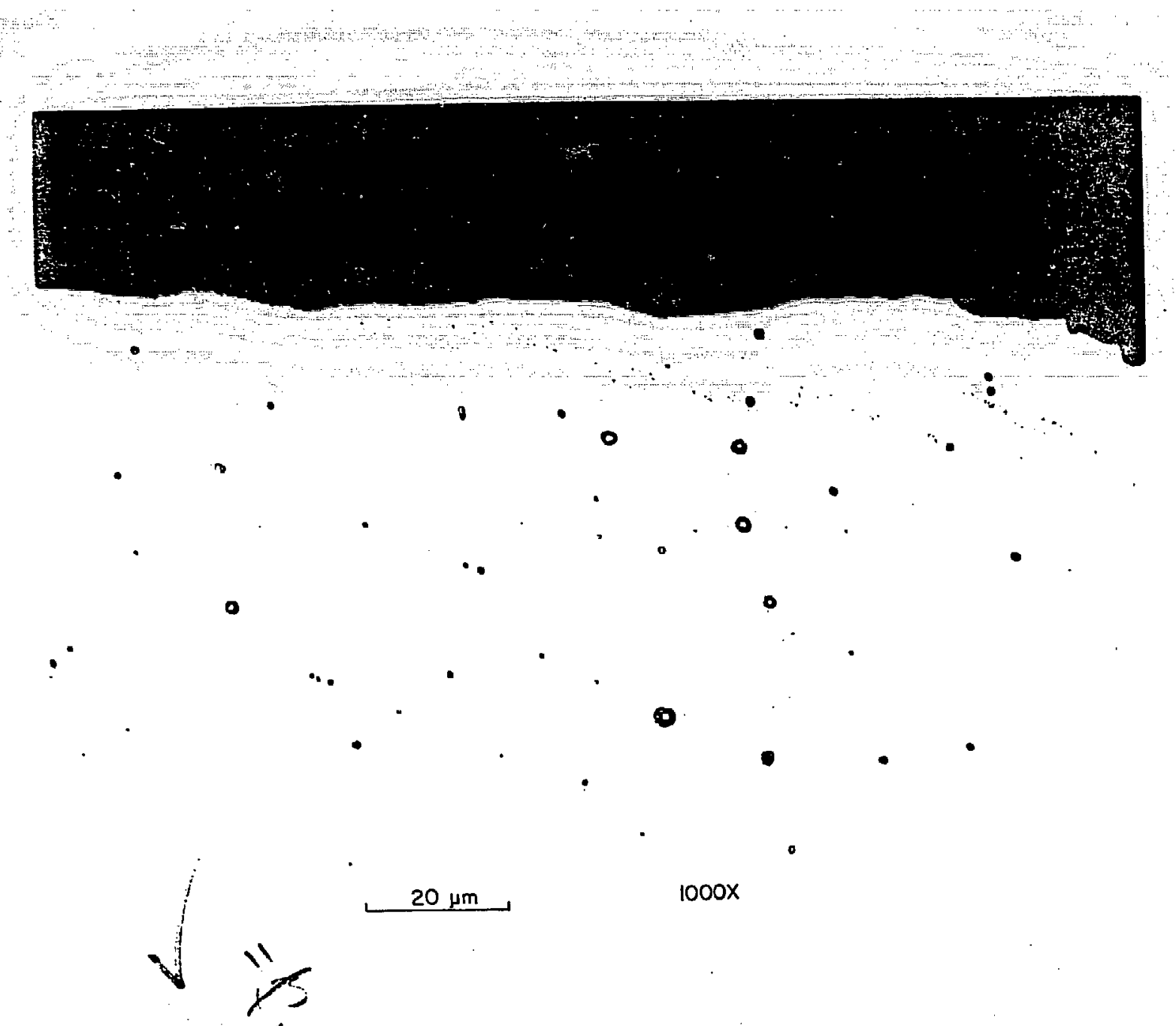

Fig. 28. Detail of the profile of the fracture path of type 309 stainless steel in area 1 of $\mathrm{Fig} .27$ showing that the fracture does not preferentially follow the ferrite (gray patches), as opposed to the matrix of the austenite. 


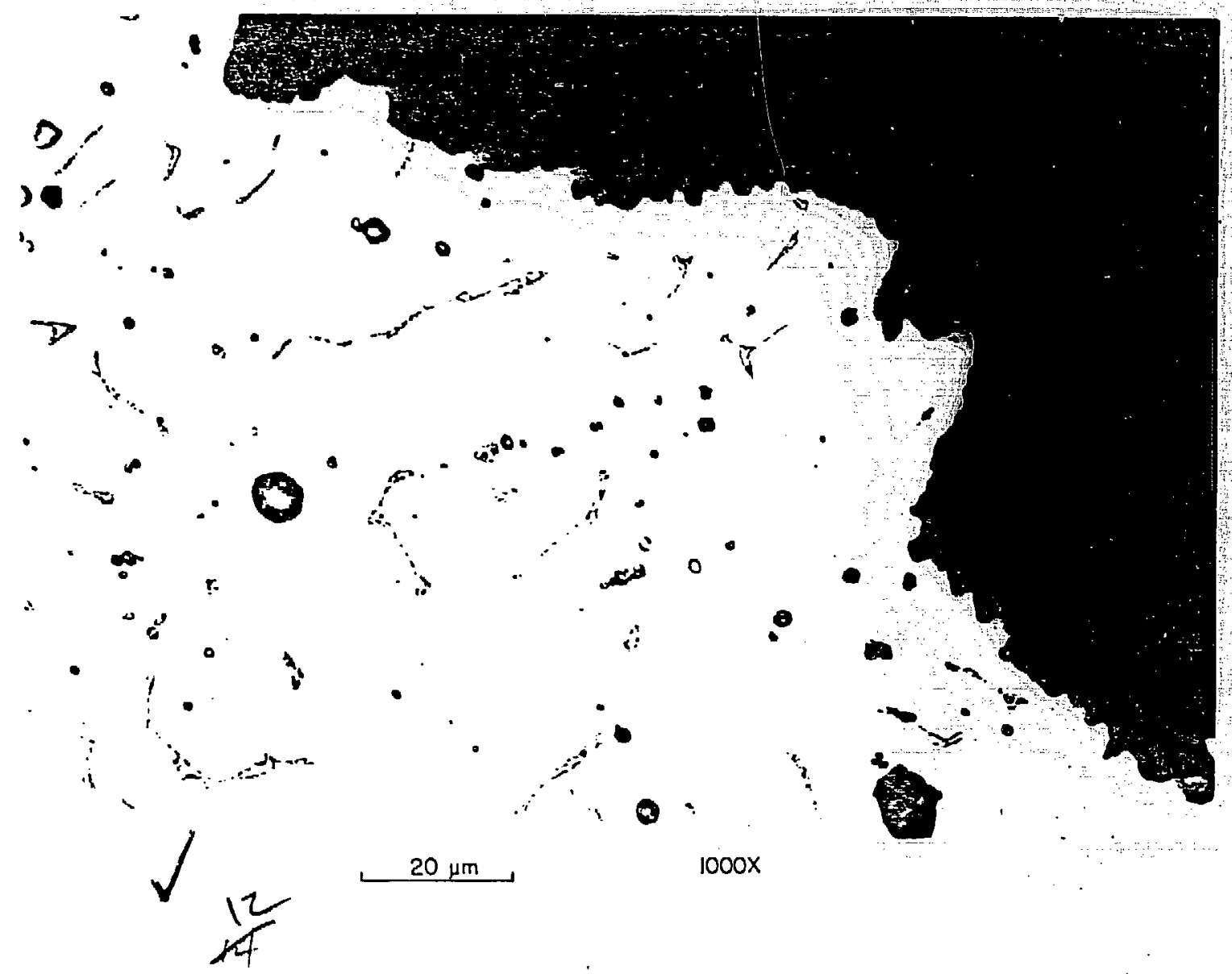

Fig. 29 . Detall of the profile of the fracture cach of type 308 stalnless steel in area 3 of Fig. 27 showing that the Eracture does not preferentially follow the $\delta$-ferrite (gray patches). 
fracture proceeds primarily through the matrix and the ferrite then fails only colncidentally. The mechanism responsible for the typically ferritic type ductile-to-brittle transition observed in our stainless steel cladding has been identified as the low temperature failure of $\delta$-ferrite regions in both types 309 and 308 cladding. This behavior may also explain the rate sensitivity observed by Hawthorne and Watson 10 in thelr impact testing of stainless steel weldments since the ferritic phases controlling the fracture are inherently rate, as well as temperature sensitive. If the cladding: on the interior of a reactor pressure vessel is to be considered structural in nature, then the potential for its rate sensitivity should also be considered. CONCLUSIONS FROM PHASE ONE AND PLANS FOR PHASE TWO

Based on a single irradiation experiment, very little degradation of the notch-impact toughness of good quality cladding would be expected. In fact, both the tensile strength and the fracture ductility were timproved slightly by irradiation. It must be stressed, however, that this is only a single case and that no conclusions, positive or negative, can be drawn regarding welding procedures or compositions leading to material different from that studied here.

Results from the highly diluted type 309 weld metal show appreciable radiation-induced degradation of notch-impact toughness, even though both the tensile strength and the tensile fracture ductility were improved slightly by irradiation. In the few documented cases where welding has produced abnormal cladding with excessive dilution in operating reactors, the radiation effects on notch-impact toughness may be cause for concern. 
By and large, the results obtained in phase one were more encouraging than some of the Indications of irradiation induced degradation reported in a recent literature review.11 Therefore, to corroborate the results of phase one and to obtain additional data for materials and irradiations conditions spectfically of interest in LWR's phase two was Initiated.

The Irradiations for phase two are currentiy in progress and should be completed early in 1986. Two capsules containing tensile, 1mpact, and $0.5 T$ compact specimens w11 be Irradiated to $2 \times 10^{23}$ neutrons $/ \mathrm{m}^{2}(\mathrm{E}>1 \mathrm{MeV})$ with an additional capsule of tensile and impact specimens reaching $5 \times 10^{23}$ neutrons $/ \mathrm{m}^{2}(\mathrm{E}>1 \mathrm{MeV})$. The material belng examined is primarily taken from. a commercially produced overlay weldment fabricated using the three-wire series arc procedure. The commercial weldment is also composed of three layers but with extreme care taken to assure the metallurgical, chemical, and mechanical properties of all layers are similar. Prelfminary results have shown that the unirradiated properties of the three-wire series arc cladding and the good quality type 308 cladding from the first serles exhibit very similar unirradiated fracture behavior.

In addition, two sets of compact specimens from the material used in phase one have been Included. The spectmens were fabricated such the tip of the precrack is in the type 308 stainless for one set and in the type 309 for the other. These specimens w111 be used to confirm the behavioral trends shown by the impact specimens in phase one.

\section{STRUCTURAL EFFECTS OF CLADDING}

TESTING SCHEME- PHASE ONE

To examine the structural effects of weld overlay cladding in a stress state relevant to an overcooling transient, a study was undertaken in which relatively large plates $(914 \times 406 \times 51 \mathrm{~mm})$ were clad on one side and tested isothermally in 4 point bending. The clad surface which was placed In tension 
by bending contained a surface flaw. The flaw was an electron beam weld, which was designed to fracture under static loading when hydrogen changed. This was to enable us to inftiate fast running fracture in the surface flaw on the plate under arbitrary Initial loading conditions.

It was anticipated that a small semielliptical flaw could be sized and the temperature and stress states chosen so that the test would result in the frangible fallure of an unclad specimen, but would pop-in and arrest in a clad specimen. This was expected because of the postulated interaction between the cladding and the running crack.

EXPERIMENTAL RATIONALE - PHASE ONE

The rationale for the experiment can be understood by considering the variation of the stress intensity factor (SIF) at maximum depth and at the surface of a growing semielliptical part-through flaw in an unclad plate vs the same values for a flaw that has been arrested at the surface; that is, in this series of tests, by the contribution of the stainless steel cladding. Figure 13 shows a plot of the SIF as calculated by the Merk1e 12,13 method for constant length $57-$ and 76-mm-long part-through flaws as a function of a/w under pure moment loading, with the surface stress approaching the material yield stress. From Fig. 13, note that at a value of $a / w$ of $\sim 0.24$ the SIFs at the maximum depth and at the surface $(\theta=0$ and $\pi / 2$, respectively) are equal for the 51-mm-long flaw. A similar situation exists for the somewhat larger 76-mm flaw at an a/w value of 0.3 . Figure 14 shows a plot of SIF values for two flaw sizes in an unclad 51-mm-thick specimen under pure bending. For appropriately selected temperature conditions such that $K_{\text {Ic }} \leftarrow 57 \mathrm{MPa} \cdot \sqrt{\mathbf{m}}$, the 
Figures 13 and 14 go here.

Fig. 13. $\mathrm{K}_{\mathrm{I}}$ variations with crack depth for a part-through surface crack of constant surface length In a 51-mm-thick plate u.ider pure bending.

Fig. 14. Predicted stress Intensity for semielliptical flaws in 51-ma-thick unclad plate under pure bending. 


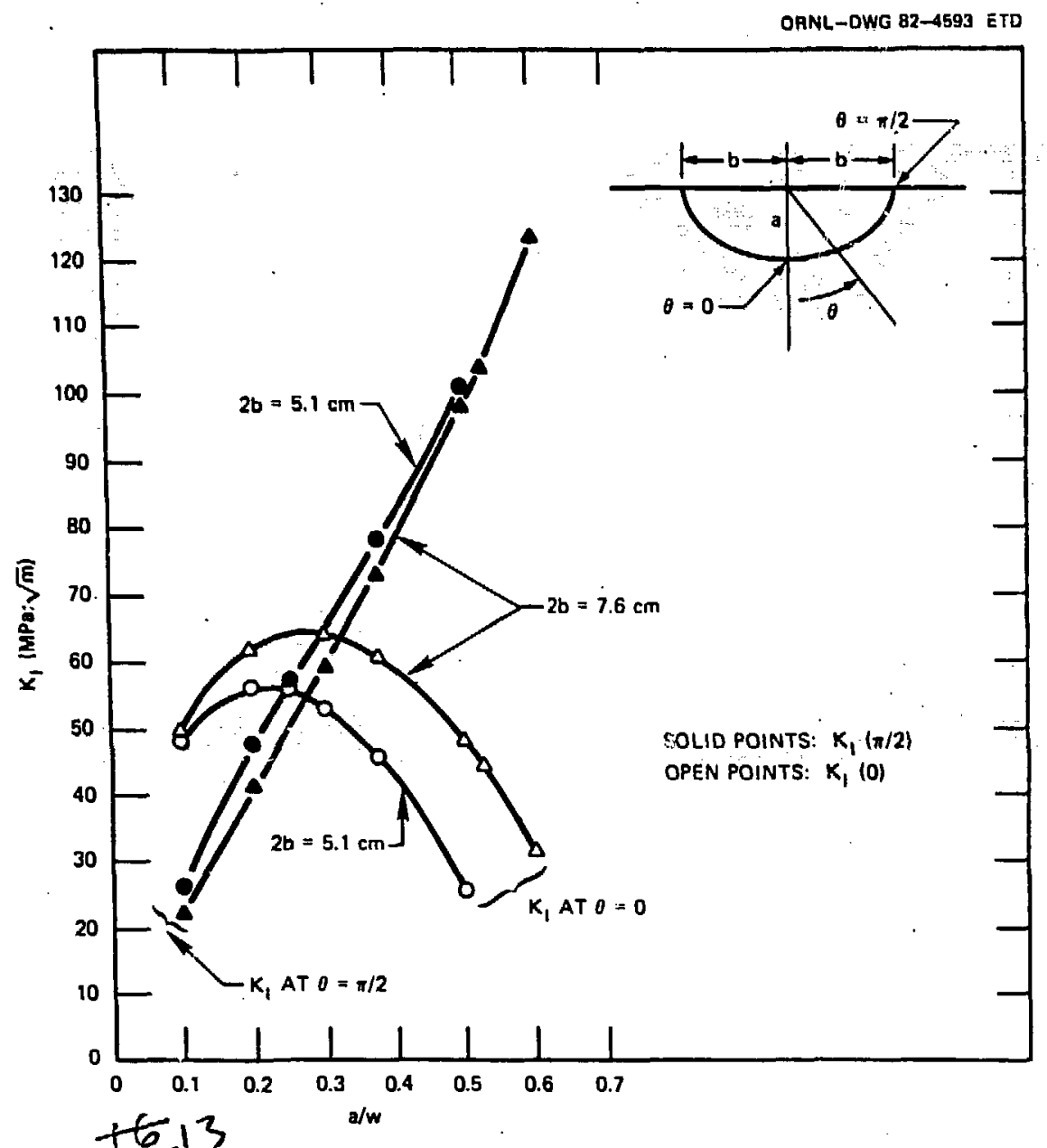

Fig. 1.2. $\mathrm{K}_{\mathrm{I}}$ variations with crack depth for a part-through surface crack of constant surface length in a 51-m-thick plate under pure bending.

ORNL-DWG 82-4594 ETD

STRESS

DISTRIBUTION

(MPa)

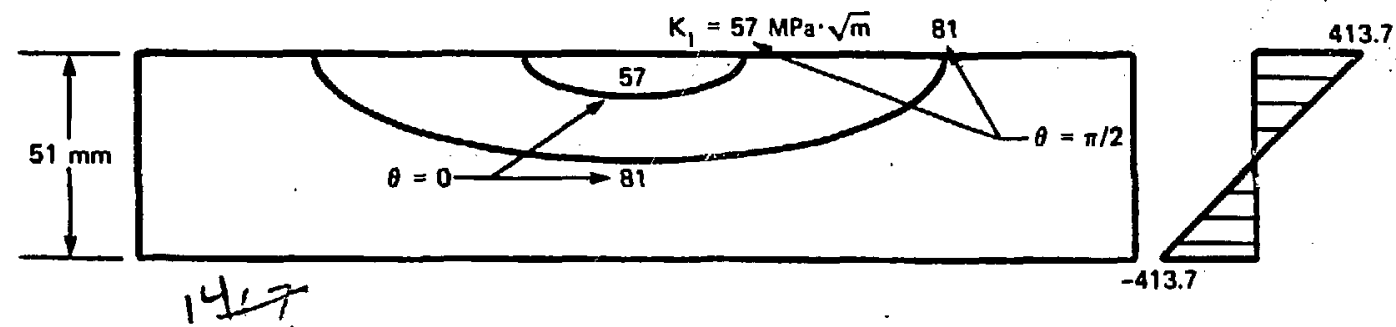

Fig. 1 . T. Predicted stress intensity for semielifptical flaws in 51-mm-thick unclad plate under pure bending. 
plot indicates that without cladding, a flaw, once initiated, grows both longer and deeper. Figure 15, plotted from the values given in Fig. 13 shows that for a flxed flaw length of $76 \mathrm{~mm}$, the $\operatorname{SIF}$ at the maximum depth $(\theta=0)$ Increases and then decreases. with depth, while it continuously increases at. the surface $(\theta=\pi / 2)$ for a deepening flaw when subjected to pure bending, with the surface stress approaching the base material yleld. These conditions Imply that for $K_{I c} \sim 40 \mathrm{MPa} \cdot \sqrt{m}$ in the base metal, a semielliptical 13-mm-deep flaw, Inttiated by the hydrogen-charging pop-in procedure, would grow in depth and length until reaching the stainless cladding. At this point, if the. cladding has an effective toughness $>125 \mathrm{MPa} \sqrt{\bar{m}}$, the flaw would be stopped from further increases in length or depth.

Fig. 15. Predicted stress intensity for 76-mm-long flaws in 51-mm-thick clad plate under pure bending.

TEST SPECIMENS AND NATERIALS - PHASE ONE

Specimens were designed as rectangular plates with four-point loading to achieve a constant-moment loading in the central zone of the specimen within which an EB-weld flaw was placed (Fig. 16). The stalnless steel cladding was 
OANL-DWG B2-4595 ETD STRESS

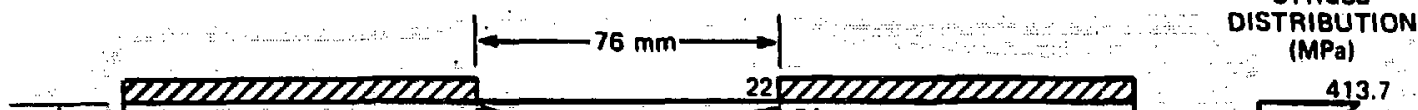

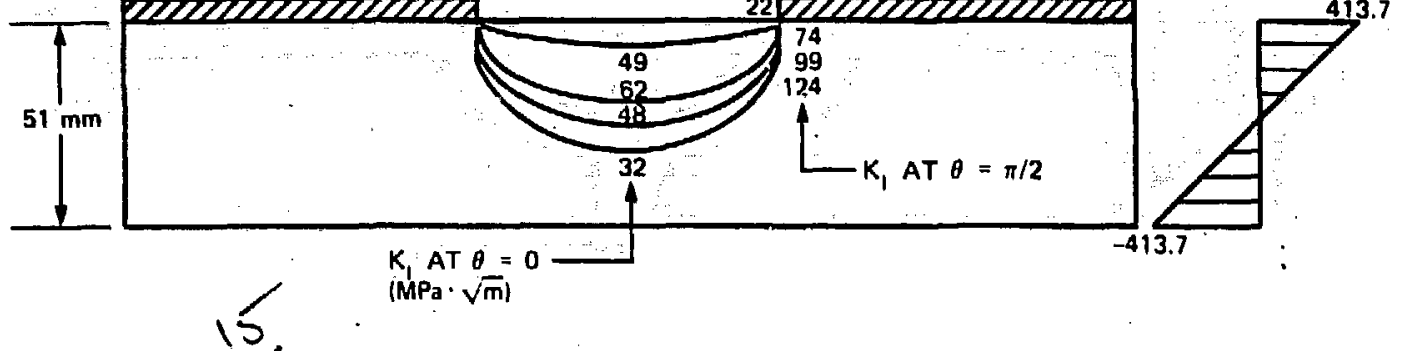

FIg. 14. Predicted stress intensity for 76-mm-long flaws in 51-mmthlck clad plate under pure bending.

OFNL-DWG 82-6651R ETD

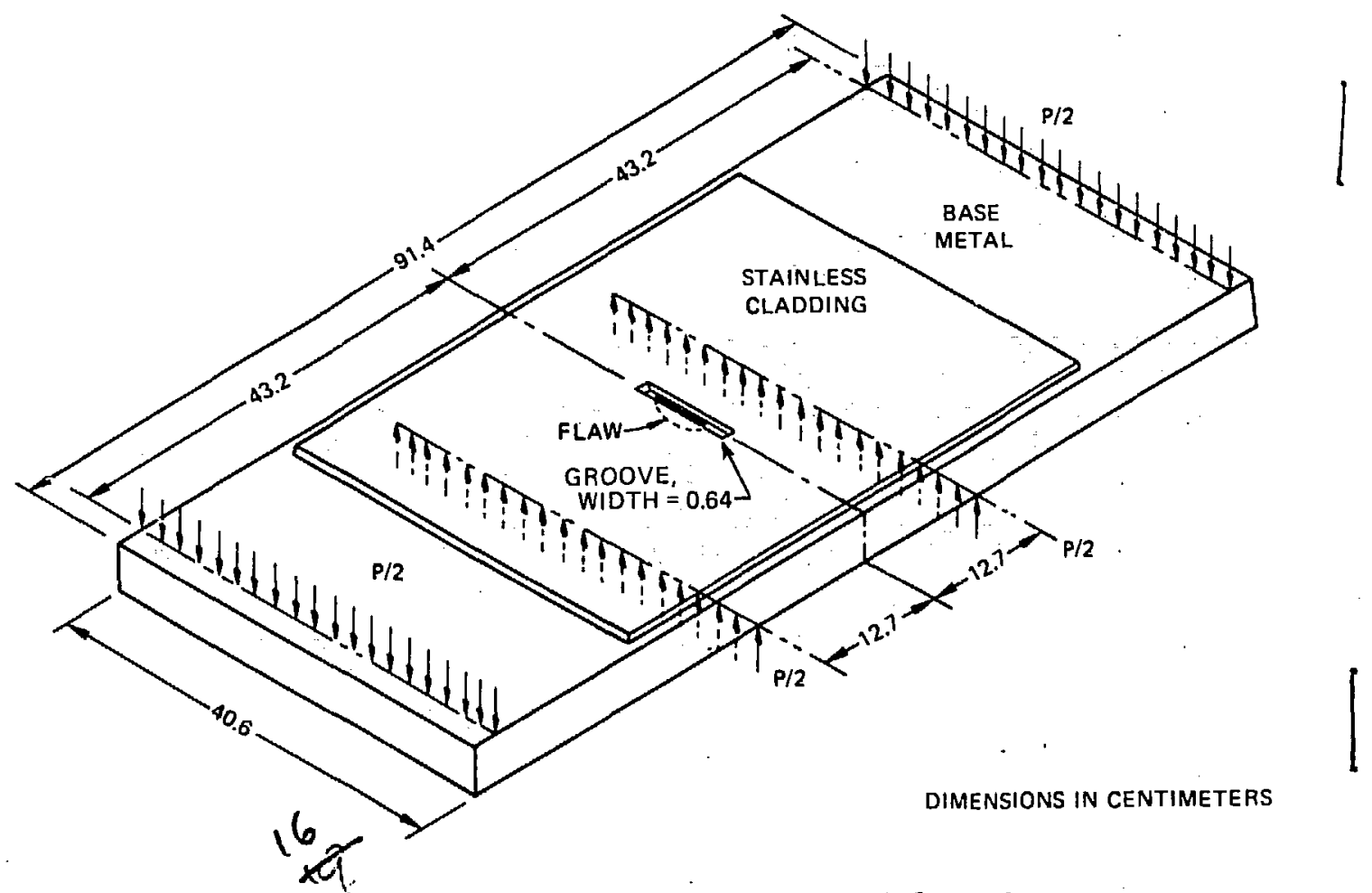

Fig. 2.3. Specimen dimensions and load locations. 
FIg. 16. Specimen dimenslons and load locations :

applied over the central area of the specimen, and a narrow slot window was then machined through the stalnless cladding down to the base metal prior to application of the EB-weld flaw.

Three types of spectmens were fabricated, unclad specimens and spectmens clad with efther a moderate toughness or a low toughness cladding. The unclad specimens were to demonstrate the lack of cladding induced arrest and consequent complete fallure of the plate under the same conditions under which a clad beam would affect arrest. The specimens clad with a moderate toughness overlay, the type $309 / 308$ with PWHT discussed previously, were designed to staulate cladding properties typical of beginning of life in an RPV. The low toughness cladding, and sigma phase embrittled type 312, was designed to simulate potential end of life properties. Both types of cladding were less tough 
than desired, the type $309 / 308$ for the reasons discussed previously. The beams clad with type 312 cladding were so brittle little useful information was gained from them and their results are not reported here.

Charpy $v-n o t c h$ Impact, tensile, and fracture toughness testing was performed on both the cladding and the base metal. The Charpy impact data of the nominal type 309 low and high energy populations described earlier are the most germaln to the plates as they represent composite fracture data of the first and second layers of cladding. They are plotted for comparison with the Charpy data for the base plate, A 533 grade B class 1, in both the LT and LS orientations, representing crack propagation across and into the plates, respectively (Fig. 17). For analysis purposes, all CVN energy vs temperature data were fitted with a hyperbolic tangent function. Even though the Impact data of the high and low populations diverge at higher temperatures, the impact energy of both sets of cladding was $12-13 \mathrm{~J}$ at the plate test temperature, only slightly higher than that of the base plate, $7-10 \mathrm{~J}$. In contrast the quasi-static inftiation toughness of cladding, $\mathrm{K}_{\mathrm{J}}$, was almost three times that of the base plate (Table 3 ). Whether this is due to rate effects related to the fallure of the $\delta$-ferrite in the cladding or other causes was not determined. The $-40^{\circ} \mathrm{C}$ test temperature was chosen to assure a franglble failure in the base plate which had a drop weight NDT of $-18^{\circ} \mathrm{C}$. Results of tensile testing at $-40^{\circ} \mathrm{C}$ are shown in Table 4.

Fig. 17. The impact toughness of the cladding slightly exceeds that of the base plate at the test temperature of the clad plates. 


\section{$7 \times g 17$}

IMPACT ENEKGY OF THE CLADDING $(12-13 \mathrm{~J})$ ONLY SLIGHTLY EXCEEDS THE BASE PLATE'S (7-10J) AT TEST TEMPERATURE

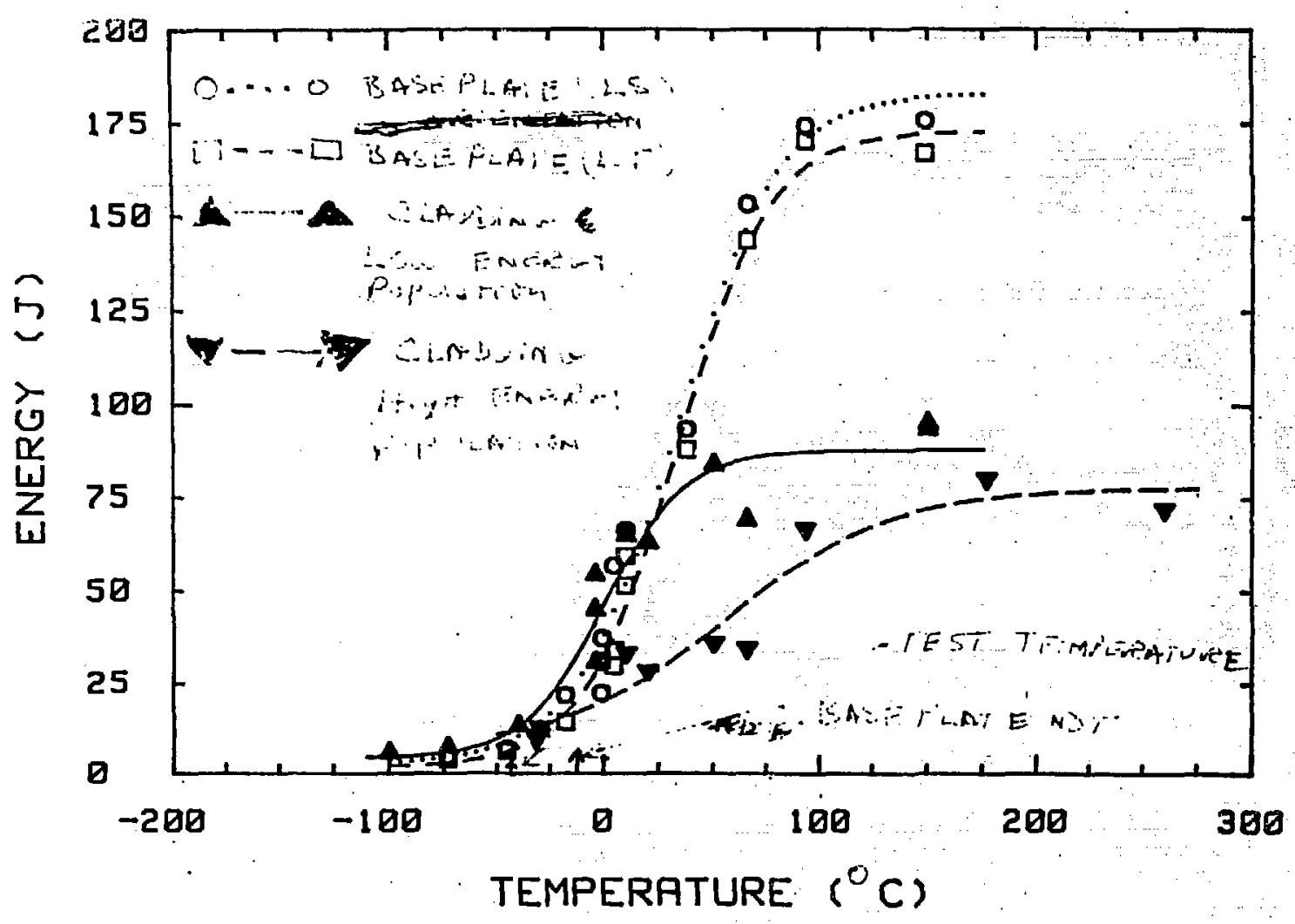

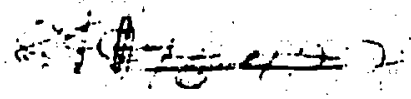

$-1,4,2,2$ 
Table 3. Fracture toughness of materlals used in the clad plate tests.

\begin{tabular}{|c|c|c|c|c|}
\hline Material & $\begin{array}{l}\text { Specimen } \\
\text { No: }\end{array}$ & $\begin{array}{l}\text { Temperature } \\
\left({ }^{\circ} \mathrm{C}\right)\end{array}$ & orientation & $\begin{array}{c}\mathrm{KJ}_{\mathrm{J}}^{\alpha} \\
(\mathrm{MPa} \cdot \sqrt{\mathrm{m}})\end{array}$ \\
\hline $\begin{array}{l}\text { A- } 533 \text { grade } B \\
\text { class } 1\end{array}$ & $\begin{array}{l}\text { CPA100b } \\
\text { CPA101 }\end{array}$ & $\begin{array}{l}-40 \\
-40\end{array}$ & $\begin{array}{l}\mathbf{L T} \\
\mathbf{L T}\end{array}$ & $\begin{array}{r}56.8 \\
80.4 \\
\end{array}$ \\
\hline Average & & & , & 68.6 \\
\hline $\begin{array}{l}308 / 309 \text { SS } \\
\text { weld metal }\end{array}$ & $\begin{array}{l}\mathrm{CP} 218^{\circ} \\
\mathrm{CP} 219^{\circ}\end{array}$ & $\begin{array}{l}-40 \\
-40\end{array}$ & $d$ & $\begin{array}{l}191.0 \\
193.0 \\
\end{array}$ \\
\hline Average & & & & 192.0 \\
\hline
\end{tabular}

acalculated from $\mathrm{J}$ at maximum load using $\mathrm{k}\}=\mathrm{EJ}$.

biT-CT specimen.

CPrecracked Charpy V-notch slow-bend specimen.

$d_{\text {As shown in Figure } 4 .}$

Table 4. Tensile properties $a$ of materials used in the clad-plate tests

\begin{tabular}{|c|c|c|c|c|c|}
\hline \multirow{2}{*}{ Material } & \multirow{2}{*}{$\begin{array}{l}\text { Temperature } \\
\left({ }^{\circ} \mathrm{C}\right)\end{array}$} & \multicolumn{2}{|c|}{$\begin{array}{l}\text { Strength } \\
\text { (MPa) }\end{array}$} & \multicolumn{2}{|c|}{$\begin{array}{c}\text { Ductility } \\
(\%)\end{array}$} \\
\hline & & Yield & Ultimate & Elongation $b$ & $\begin{array}{l}\text { Reduction } \\
\text { of area }\end{array}$ \\
\hline $\begin{array}{l}\text { A-533 grade } B \\
\text { class } 1\end{array}$ & -40 & 490.8 & 685.4 & 20.7 & 61.7 \\
\hline $\begin{array}{l}\text { 308/309 SS weld } \\
\text { metal }\end{array}$ & -40 & 324.7 & 874.7 & 43.7 & 47.0 \\
\hline
\end{tabular}

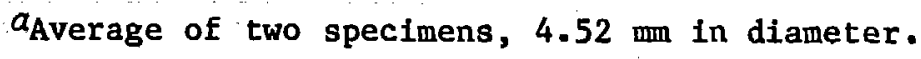

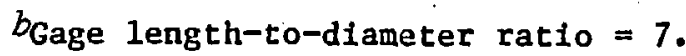

To provide baseline values on the material used as the base plate, crackarrest testing was also performed. Crack-arrest specimens were fabricated from broken halves of the clad-plate specimens in the LT orientation. This orientation corresponded to the extension of the flaw in the clad-plate 
experiments across the width of the plate. The specimens were of the weldembrittled, transverse-loaded, sp.lit-pin type recommended by the latest draft of the proposed ASTM standard on crack-arrest testing. They were $25.4 \mathrm{~mm}$ thick with planar dimensions of 152.4 and $148.2 \mathrm{~mm}$. These data allow a direct comparison to be made between the values of crack arrest calculated for the clad plates and those of the base plate itself to determine if the cladding did indeed enhance the structural resistance of the clad structure.

TESTING EQUIPMENT AND SEQUENCE - PHASE ONE

An existing 1-MN servo-hydraulic testing machine was modified to Impose four-point bending on the specimens (Fig. 18). In addition to applying the controlled loading, the fixture was also designed to eliminate in-plane loading as a result of bearing constraint caused by temperature changes during the loading process. Other features incorporated with the modiffcation included a liquid-nitrogen cooling system for the test specimen, a system for hydrogen charging of the EB weld to induce crack propagation under load, and a plastic shield to protect operating personnel from injury caused by possible missiles and splashing liquid nitrogen or sulfuric acid.

The test procedure developed for the specimens included the following steps: (1) Instrumentation of specimen; (2) insertion and alignment of specimen in the text fixture; (3) attachment of sensors to recorders and data acquisition systems; (4) cooling of the specimen to the preselected test temperature; (5) loading of the specimen to a target load, typically corresponding to incipient yielding at the surfaces of the plate;

(6) maintenance of the load with the testing machlne in displacement contro1; (7) iydrogen charging of the EB-weld flaw; and (8) continuous and/or periodic monitoring of specimen load, strain, flaw crack-opening displacement (COD), 
Fig. 18. Section elevation of clad plate task test setup.

and temperature until efther failure of the specimen or pop-in and arrest of the flaw occurred. If pop-in and arrest occurred, the specimen was removed from the machine, heat-tinted, and subsequently broken frangibly to permit a view of the arrested flaw profile.

Additional details on test materials, specimens and procedures can be obtained elsewhere. 2

TEST RESULTS AND DISCUSSION - PHASE ONE

Efforts were made to use the test procedures described above; however, departures occurred during the experiments. A brief description of each test is given below along with the results.

One unclad plate, CP-1A, was tested. This test provided a demonstration of the hypothesis that at the loading conditions chosen, an unclad specimen should fail. The test procedure was carried out as planned, with the fully 


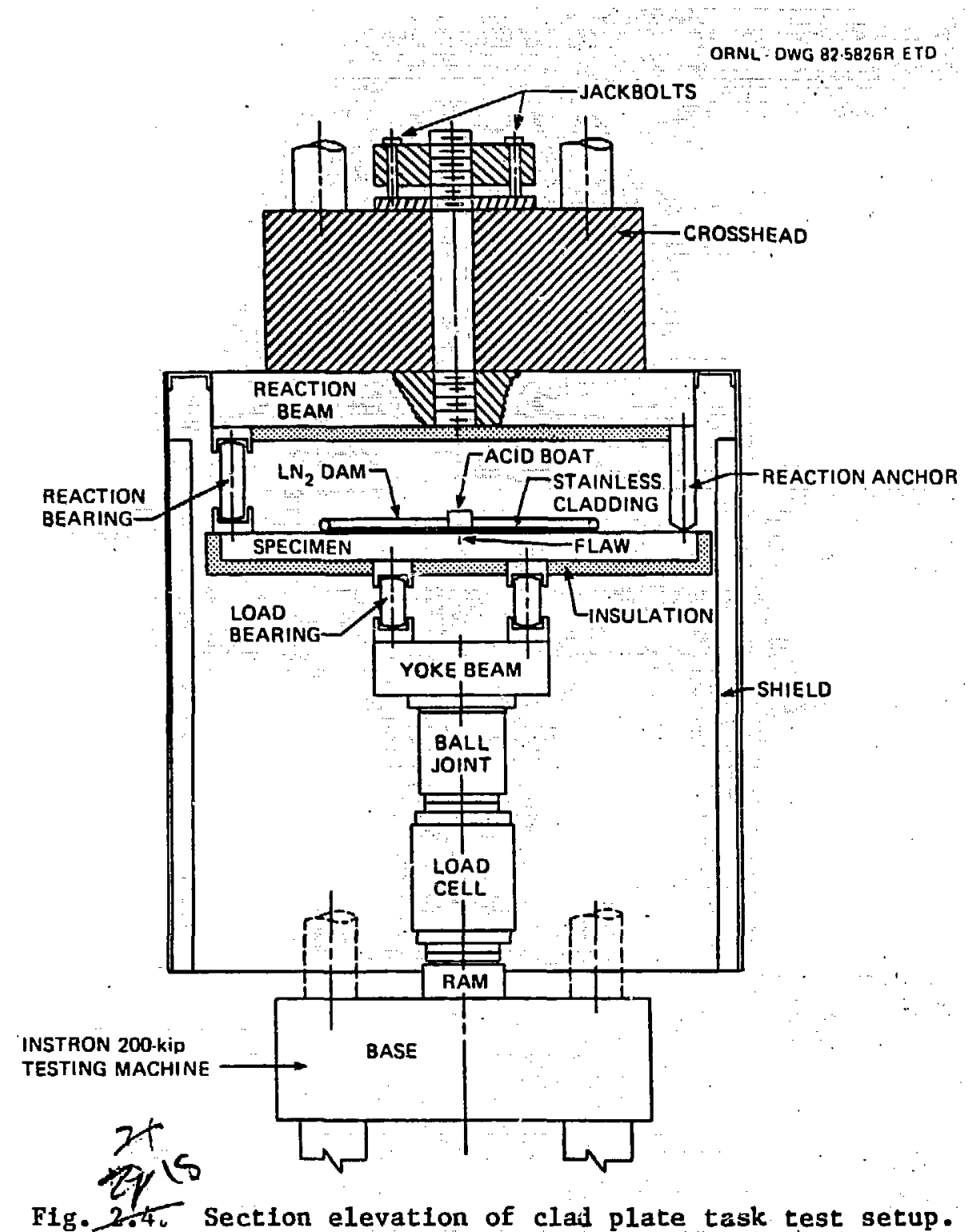


instrumented specimen reaching and sustaining a load of $622.8 \mathrm{kN}$ at $-40^{\circ} \mathrm{C}$, corresponding to incipient yielding of the surface fibers. Hydrogen charging was initiated, and the specimen fractured frangibly into two halves. The instrumentation of the plate, which is typical for all other tests as we11, is shown in F1g. 19. Foll-type strain gages, weldable COD gages, and tack-welded thermocouples were included. On examination of the fracture surface, the crack appeared to have initiated in the brittle EB weld and rapidly propagated through the entire plate.

Fig. 19. Unclad plate CP-1A shown after all instrumentation has been applied.

Four plates with $308 / 309$ cladding (CP-3, $\mathrm{CP}-5, \mathrm{CP}-8$, and $\mathrm{CP}-9$ ) were tested. These tests were intended to demonstrate and define the contribution that the stainless steel cladding would make to the composite structural resistance of the spectmen to dynamic fallure. Specimen $\mathrm{CP}-3$ wa; cocind to $-40^{\circ} \mathrm{C}$, and loading toward the target incipient yielding load of $596 . ? \mathrm{kN}$ was begun. At a load of $327.8 \mathrm{kN}$, a pop-in occurred. Although calculations from the COD gage results indicated a pop-in from a flaw of EB-weld size, the 

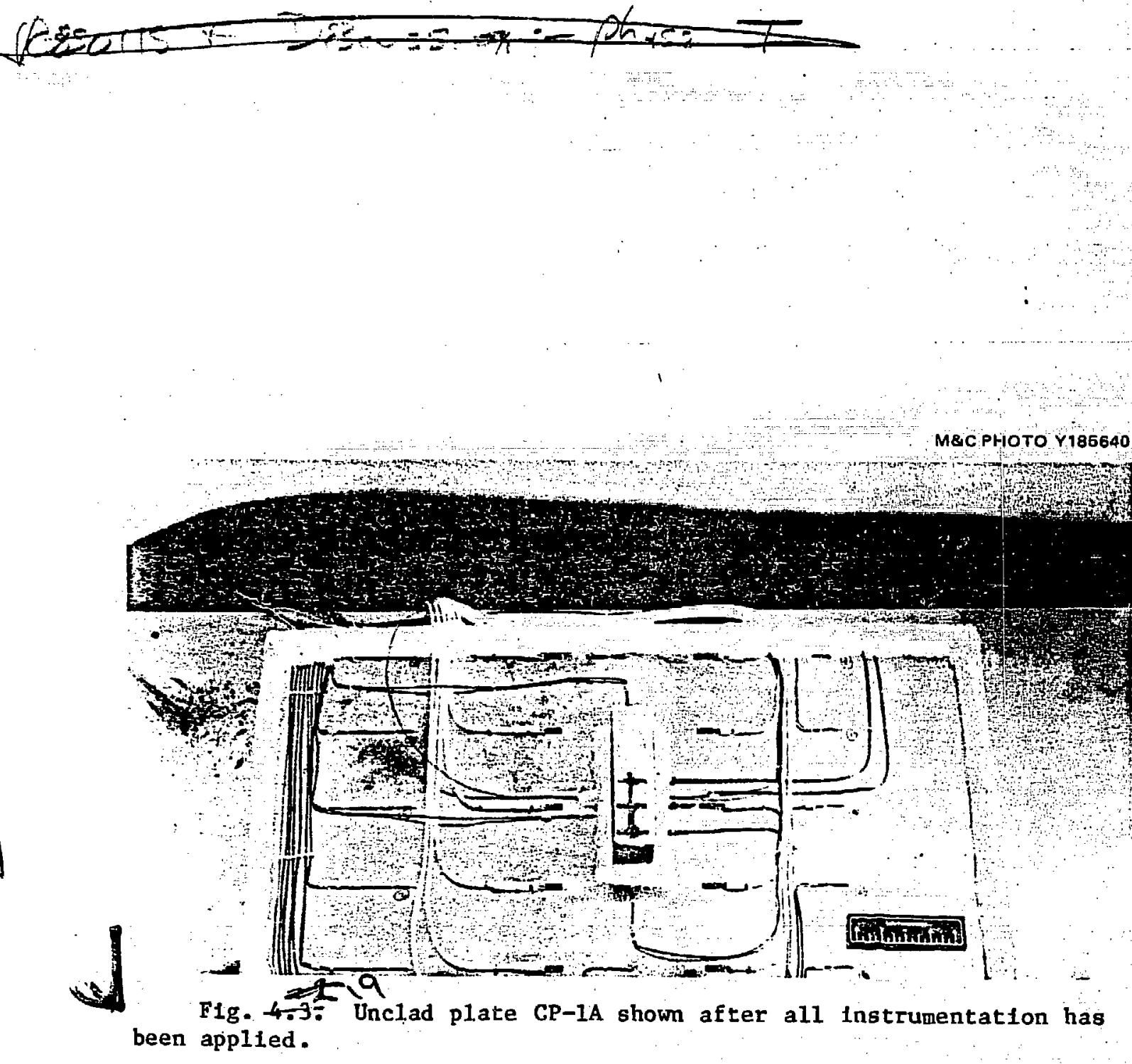
extent of the event was uncertain, and loading was continued to the targer load. The specimen then was hydrogen-charged for about $35 \mathrm{~h}$, at which point It was concluded that no further events would occur. The specimen was unloaded and heat-tinted. The cladding on the specimen was then sawed (across the specimen) coplanar with the pop-in down to the bottom of the groove surrounding the EB weld to facilitate final fracture of the specimen. The specimen was cooled to $-100^{\circ} \mathrm{C}$ and reloaded monotonically until fallure occurred at $364.6 \mathrm{kN}$.

The pop-in at $327.8 \mathrm{kN}$ (Fig. 20) appears to have propagated through the entire EB weld and into the base metal in the depth direction, but not along the surface of the cladding where it seems to have been pinned at the intersection of the EB weld and cladding. Upon final fracture, which was frangible, the crack did run through both the ferritic base metal and the remaining austenitic cladding.

Fig. 20. Deta1l of pop-1n in area of type $309 / 308$ stainless steel clad plate CP-3. Note that crack ran through the EB weld (dark smooth area) into the base metal (dark rough area) In the depth direction but not along the surface where it was pinned by cladding. 

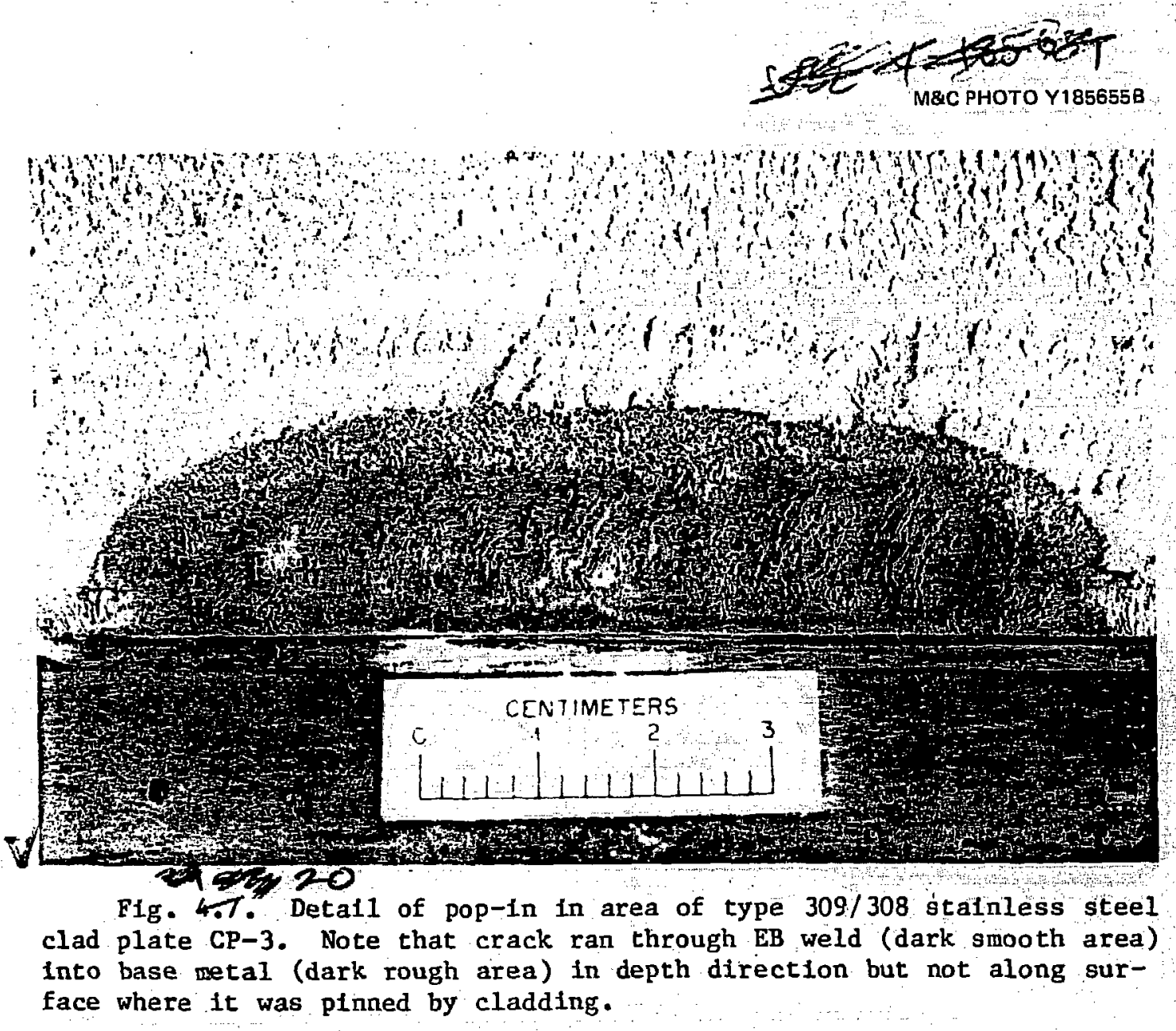
Specimen $\mathrm{CP}-5$ was cooled to $-40^{\circ} \mathrm{C}$ and loaded to incipient yielding (at the base-plate/weld-metal interface) at $667.2 \mathrm{kN}$, and hydrogen charging was begun. The specimen falled frangibly. in about $3 \mathrm{~h}$. The fracture surface exhibited flat fracture, which appears to have originated in the EB weld and run throughout the plate.

Specimen CP-8 was cooled to $-40^{\circ} \mathrm{C}$ and, slmilar to CP-3, pop-in occurred during loading at $291 \mathrm{kN}$. The specimen was unloaded, heat-tinted, and loaded monotonically at $-73^{\circ} \mathrm{C}$ until fallure occurred at $380 \mathrm{kN}$. The cladding was not sawed to facilitate fracture in this specimen. The flaw had propagated into the base metal during the test but remained pinned at the cladding/EB-weld Interface.

To define the upper limit of arrest, a load of $418 \mathrm{kN}$ was chosen as the test load for specimen $\mathrm{CP}-9$, intermedlate between specimens $\mathrm{CP}-5$ and $\mathrm{CP}-8$. Posttest measurements of the flaw geometry revealed it to be considerably different from that assumed in the pretest calculations so that the actual stress intensity factor at arrest was considerably lower than expected. Specimen CP-9 was cooled to $-40^{\circ} \mathrm{C}$, loaded to $418 \mathrm{kN}$, and hydrogen charged. The flaw popped In and arrested. The specimen was unloaded, heat-tinted, and loaded monotonically at $-73^{\circ} \mathrm{C}$ unt1l fallure occurred at $393.7 \mathrm{kN}$. At the pop-in, the flaw tunneled within the base metal without contacting the cladding. Two methods were initially used to calculate the stress intensity factor at arrest as a function of angular postition (Table 5): the method developed by Merk1e 12,13 and the method developed by Raju and Newman.14 Later threedimensional finite-element calculations were also made using the ORVIRT program ${ }^{15}$ (Table 5). No attempt was made to estimate and to incorporate bimetallic and residual stresses in the calculations or to assess the effect of plastic flow at test loading. As Initlaily planned, test loading to obtain 
Table 5. Tabulation of calculated stress-intensity factor data

\begin{tabular}{|c|c|c|c|c|c|c|c|c|c|c|c|c|c|c|}
\hline \multirow{2}{*}{$\begin{array}{l}\text { Spec1- } \\
\text { men } \\
\text { No. }\end{array}$} & \multirow{2}{*}{$\begin{array}{l}\text { Flawa } \\
\text { type }\end{array}$} & \multirow{2}{*}{$\begin{array}{l}\text { Flaw } \\
\text { depth } \\
a \\
(\mathrm{~cm})\end{array}$} & \multirow{2}{*}{$\begin{array}{l}\text { Flaw } \\
\text { half- } \\
\text { length } \\
\text { b } \\
\text { (cm) }\end{array}$} & \multirow{2}{*}{$\begin{array}{l}\text { Plate } \\
\text { depth } \\
\theta=\pi / 2 \\
\text { plane } w \\
\text { (ca) }\end{array}$} & \multirow{2}{*}{$\underset{(\mathrm{kN})}{\operatorname{Load} b}$} & \multirow{2}{*}{$\begin{array}{l}\text { Stress } c \\
(\mathrm{MPa})\end{array}$} & \multirow{2}{*}{$\begin{array}{l}\text { straind } \\
\text { micro- } \\
\text { strain }\end{array}$} & \multirow{2}{*}{$\begin{array}{l}\text { Tempera- } \\
\text { tured } \\
\left({ }^{\circ} \mathrm{C}\right)\end{array}$} & \multicolumn{6}{|c|}{$\begin{array}{c}\text { Stress inteasity factor, } K_{\Upsilon}(\theta) \\
(\mathrm{MPa} \cdot \sqrt{\text { III })}\end{array}$} \\
\hline & & & & & & & & & Methode & $\theta=0$ & $\theta=\pi / 6$ & $\theta=\pi / 4$ & $\theta=\pi / 3$ & $\theta=\pi^{\prime} 2$ \\
\hline$C P-1 A$ & I & 1.43 & 3.35 & 5.40 & 622.8 & 481.0 & 2050 & -40 & $\begin{array}{l}\mathrm{M} \\
\mathrm{RN}\end{array}$ & $\begin{array}{l}72.8 \\
67.8\end{array}$ & $\begin{array}{l}75.9 \\
67.5\end{array}$ & $\begin{array}{l}78.0 \\
67.0\end{array}$ & $\begin{array}{l}78.8 \\
65.8\end{array}$ & $\begin{array}{l}68.0 \\
66.4\end{array}$ \\
\hline $\mathrm{CP}-3$ & $I$ & 1.57 & 4.76 & 4.96 & 327.8 & 246.6 & 1413 & -40 & $\begin{array}{l}M \\
R N\end{array}$ & $\begin{array}{l}40.5 \\
36.9\end{array}$ & $\begin{array}{l}42.8 \\
36.9\end{array}$ & $\begin{array}{l}44.5 \\
36.7\end{array}$ & $\begin{array}{l}45.7 \\
36.4\end{array}$ & $\begin{array}{l}34.2 \\
35.6\end{array}$ \\
\hline $\mathrm{CP}-3$ & A & 2.18 & 4.76 & 4.96 & 327.8 & 246.6 & 1413 & -40 & $\begin{array}{l}M \\
\text { RN } \\
0\end{array}$ & $\begin{array}{l}37.5 \\
30.2 \\
33.7\end{array}$ & $\begin{array}{l}42.1 \\
30.7 \\
36.8\end{array}$ & $\begin{array}{l}45.5 \\
31.4 \\
39.1\end{array}$ & $\begin{array}{l}48.3 \\
32.9 \\
42.3\end{array}$ & $\begin{array}{l}47.6 \\
45.3 \\
34.9\end{array}$ \\
\hline$C P-5$ & $\mathbf{I}$ & 1.51 & 2.12 & 4.81 & 667.2 & 478.9 & 4473 & -40 & $\begin{array}{l}M \\
\text { RN } \\
0\end{array}$ & $\begin{array}{l}51.5 \\
49.2 \\
51.1\end{array}$ & $\begin{array}{l}55.9 \\
50.5 \\
40.4\end{array}$ & $\begin{array}{l}59.6 \\
52.5 \\
51.0\end{array}$ & $\begin{array}{l}63.6 \\
56.1 \\
63.0\end{array}$ & $\begin{array}{l}77.8 \\
73.3 \\
32.2\end{array}$ \\
\hline CP. 7 & I & 1.15 & 3.33 & 4.86 & 413.7 & 318.2 & 1353 & -62 & $\begin{array}{l}\text { M } \\
\text { RN }\end{array}$ & $\begin{array}{l}46.6 \\
43.8\end{array}$ & $\begin{array}{l}48.2 \\
43.6\end{array}$ & $\begin{array}{l}49.5 \\
43.2\end{array}$ & $\begin{array}{l}50.0 \\
42.3\end{array}$ & $\begin{array}{l}37.3 \\
37.5\end{array}$ \\
\hline$C P-8$ & I & 1.14 & 3.26 & 4.89 & 291.4 & 233.1 & 1360 & -40 & $M$ & 33.9 & 35.1 & 36.0 & 36.4 & 27.5 \\
\hline$G P-8$ & A & 1.47 & 3.01 & 4.89 & 291.4 & 233.1 & 1360 & -40 & $\begin{array}{l}M \\
0\end{array}$ & $\begin{array}{l}33.7 \\
30.7\end{array}$ & $\begin{array}{l}34.0 \\
31.6\end{array}$ & $\begin{array}{l}35.3 \\
32.4\end{array}$ & $\begin{array}{l}36.1 \\
33.7\end{array}$ & $\begin{array}{l}34.9 \\
21.3\end{array}$ \\
\hline $3 P-8$ & IR & 1.47 & 3.01 & 4.89 & 380.3 & 304.2 & 1640 & -73 & $M$ & 44.0 & 44.3 & 46.1 & 47.2 & 45.5 \\
\hline CP-9 & A & 1.95 & 5.03 & 4.01 & 418.1 & 159.7 & 1690 & -40 & $M$ & 15.9 & 19.3 & 22.3 & 25.0 & 26.0 \\
\hline$C P-9 f$ & A & 3.06 & 5.03 & 5.12 & 418.1 & 359.2 & 1690 & -40 & $\mathbb{M}$ & 36.3 & 55.3 & 62.7 & 63.0 & 103.7 \\
\hline $\mathrm{CP}-9$ & A & 1.95 & 5.03 & 4.01 & 418.1 & 159.7 & 1690 & -40 & 0 & 30.7 & 32.4 & 33.7 & 36.6 & 30.3 \\
\hline
\end{tabular}

$a_{I}=$ inftiation, $A=$ arrested, and IR = inftiated on reloading. byeasured.

ccalculated at flaw $\theta=\pi / 2$ plane.

dMeasured average surface.

eN = Merkle method, $\mathrm{RN}=$ Raju-Newman method, and 0 = ORVIRT method.

fCalculation based on gross section. 
stresses approaching yield at the stainless base-metal interface would result in plastic flow of the stainless cladding. The strain reported in Table 5 is the average strain on the stainless clad surface within the constant moment zone of the four-point beam loading of the specimens. For the conditions of the experiments performed with yielding of the cladding, it was assumed that for a first approximation, the stress intensity factor could be evaluated by assuming the deformation of the entire beam was governed by the elastic beha? vior of the base material.

The Initial interpretation of the flaw arrest experienced at the stainless base-metal interface for specimens $\mathrm{CP}-3$ and $\mathrm{CP}-8$ was that the arrest was a result of the stainless cladding. However, arrest within the base metal for specimen CP-9 raised the question of the validity of the approximate analyses used in light of the actual specimen geometry prompting the additional ORVIRT stress intensity factor calculations given in Table 5, the results of which are shown with the simpler method as functions of the polar angle in Fig. 21 for specimen $\mathrm{CP}-3$, as an example.

It is evident that the fabrication techniques employed were inadequate. The intent was to machine a groove precisely down to the interface between the stainless cladding and base metal and apply the EB weld in the bottom of the grooves in the base metal. The grooves for $\mathrm{CP}-3, \mathrm{CP}-5$, and $\mathrm{CP}-8$ were machined too shallow. The groove for CP-9 was controlled in depth by an etching technique, and while all traces of the cladding layer were removed, the result was a deep groove appreciably lower than the mean depth of the weld interface. 
Fig. 21. Stress intensity for arrested flaw in specimen CP-3 as function of polar angle as calculated by Merkle, Raju-Newman, and ORVIRT methods.

The simplified methods of analysis employed assumed a plane surface at the bottom of the groove for the calculation of the stress intensity factor because the calculations were based on the Intersection of a flaw with a free surface; that is, the effect of the groove in the cladding was ignored. In addition, the flaw was assumed to have a semielliptical shape. on the other hand, the ORVIRT calculations used the posttest-determined shape of the groove and flaw to calculate the stress intensity factor. The resulting improved stress-intensity factor calculation agreed reasonably well with the simpler methods for spectmens $\mathrm{CP}-3, \mathrm{CP}-5$, and $\mathrm{CP}-8$ which contained a shallow groove except for the zone where the polar angle approached $90^{\circ}$, near the intersection of the flaw with the bottom of the groove in the cladding. Here the stress intensity factors were elevated, presumably due to the stress concentration effects of the $6.25-\mathrm{mm}-$ wide groove. For specimen CP-9, which contained the deep groove and for which the simplified methods were inadequate, only the ORVIRT calculation appeared useful. 
71

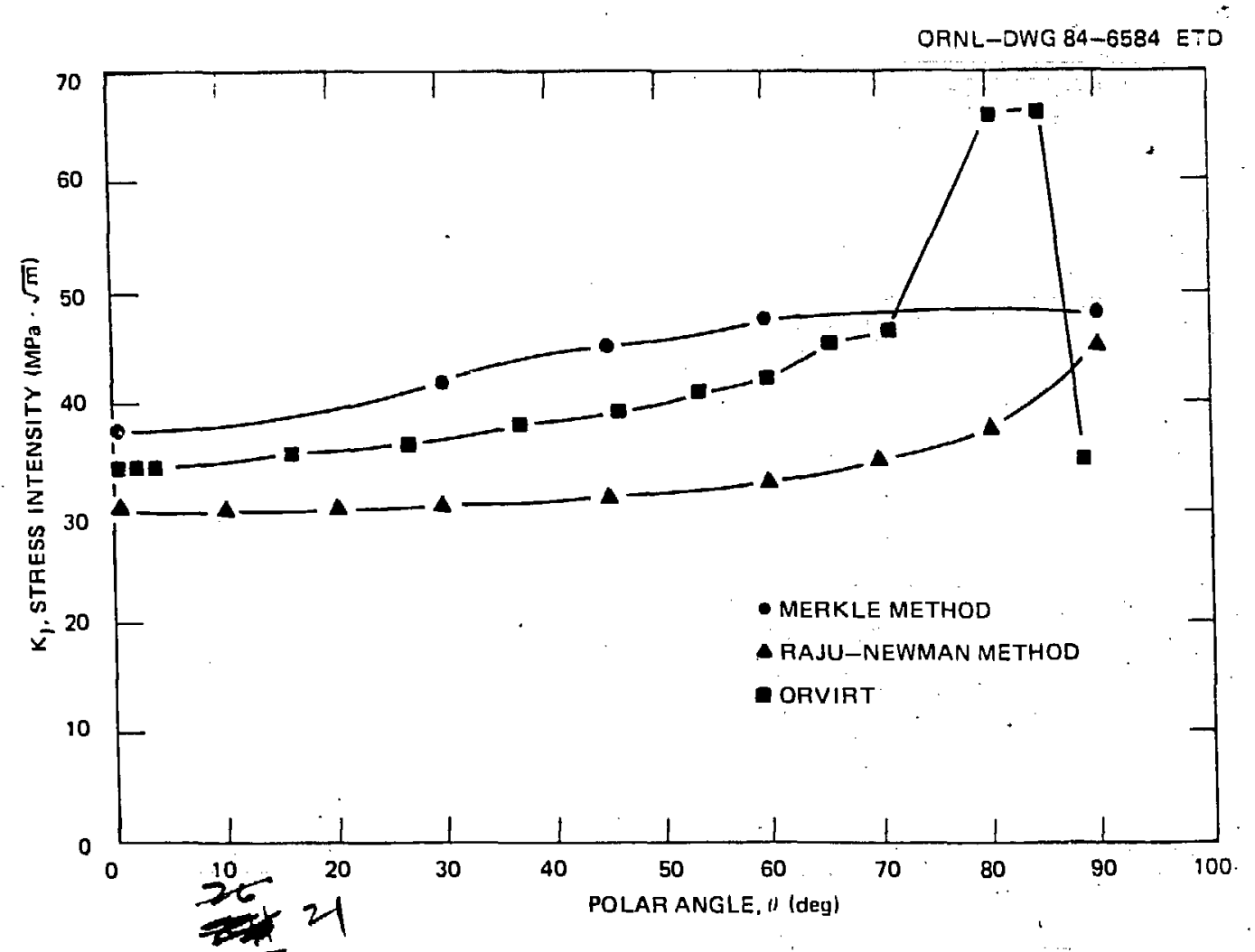

Fig. 4.2I. Stress intensity for arrested flaw in specimen $\mathrm{CP}-3$ as function of polar angle as calculated by Merkle, Raju-Newman, and ORVIRT methods. 
To see what effect the cladding had on the crack-arrest properties of the composita clad-plate specimens, it is useful to compare the maximum values of stress intensity factor calculated for the plate specimens at the arrest of the pop-ins with values for the base metal. For this purpose it was judged most reasonable to use the peak values of $K_{I}$ taken from the ORVIRT, the values for which are listed in Table 6 . This is because the peak values reflect the stress concentration effects of the groove, which appear to be significant near the cladding-base metal interface although not elsewhere. The reason for using the peak values rather than those at $\theta=\pi / 2$ was that the steeply falling segments of the ORVIRT curves between the peaks and $\theta=\pi / 2$ are not considered accurate, because of finite-element distortion effects which appear to have developed very near the ends of the flaws. The results for the crackarrest specimens and the clad-plate specimens shown in Fig. 22 indicate that two of the values of arrest toughness calculated for the clad-plate experiments (CP-8 and -9) colncide closely with those obtalned using crack-arrest specimens; the third (CP-3), however, is slightly higher. The stress intensity factor for clad-plate specimen $\mathrm{CP}-5$, which did not arrest, was calculated for the flaw geometry and loading conditions at initiation and because of the

Table 6. Maximum near-surface stress intensity factor values calculated by ORVIRT for plates with $308 / 309$ cladding

\begin{tabular}{lllc}
\hline Plate & Condition & $\begin{array}{c}\text { Angle } \\
(\mathrm{deg})\end{array}$ & $\begin{array}{c}\mathrm{K}_{\mathrm{I}} \\
(\mathrm{MPa} / \sqrt{\mathrm{m}})\end{array}$ \\
\hline $\mathrm{CP}-3$ & Arrest & 85 & 67 \\
$\mathrm{CP}-5$ & Initiation & 90 & 101 \\
$\mathrm{CP}-8$ & Arrest & $80-85$ & 50 \\
$\mathrm{CP}-9$ & Arrest & 89 & 57 \\
\hline
\end{tabular}


Fig. 22. Comparing the crack-arrest values calculated for clad-plate specimens that arrested with those obtained from crack-arrest specimens indicates only a possibility that the cladding enhanced the toughness of the structure.

load reached, was well in excess of the values obtained with the crack arrest specimens. Overall the comparisons made between the crack-arrest specimens and the clad-plate experiments show that there may be limited ability of the moderate toughness cladding examined to enhance structural resistance to crack extension. However, the present data are not entirely conclusive because orly a modest increase, if any, in the calculated arrest toughness of the cladplate specimens beyond the base material scatter band was observed. To provide a more definitive answer regarding if and indeed how much structural enhancement the cladding could yield in this geometry would require additional testing. Inftlal loading conditions would need to be reached that 


\section{5}

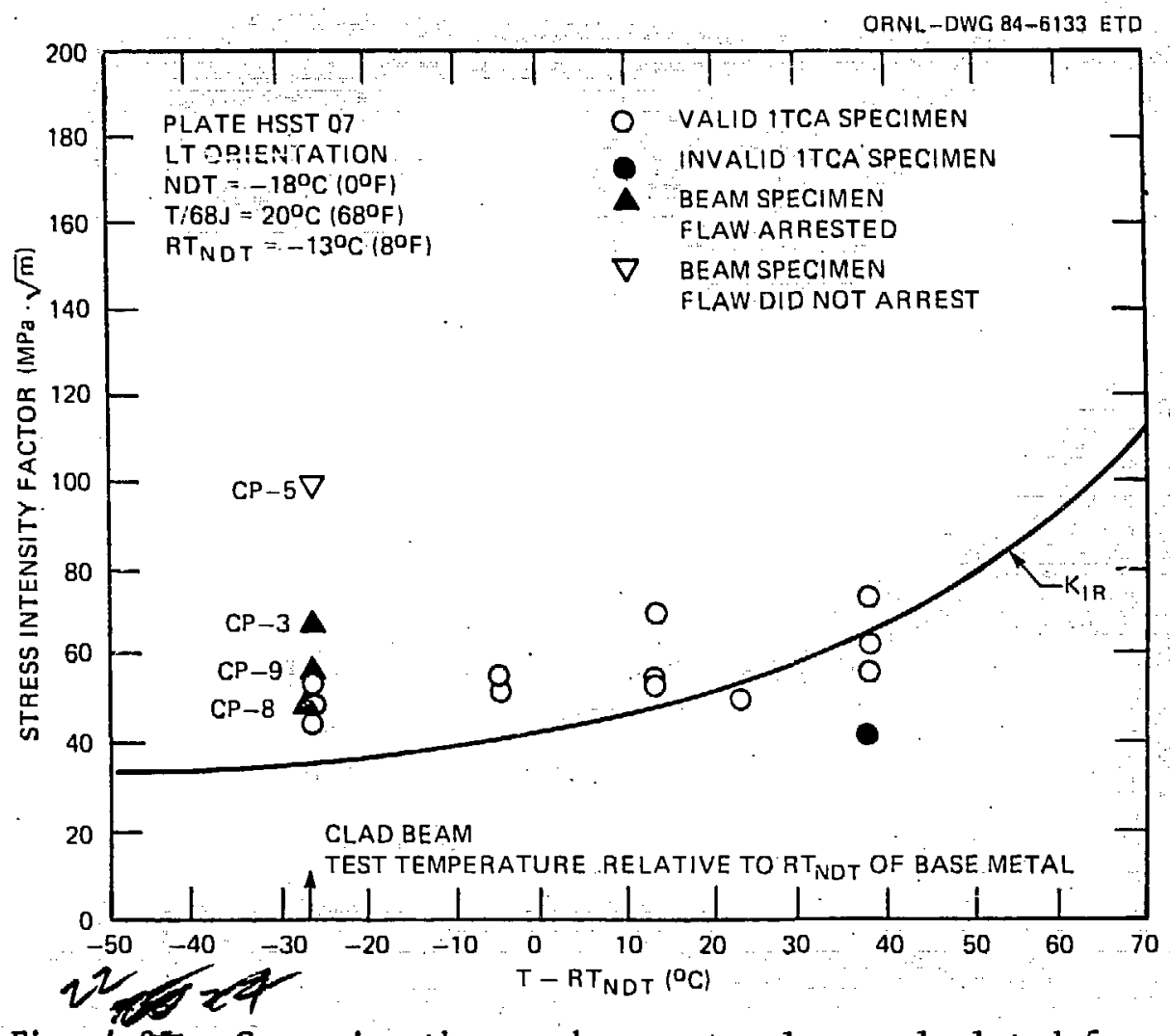

Fig. 4-25. Comparing the srack-arrest values calculated for cladbeam specimens that arrested with those obtained from crack-arrest specimens Indicates only a possibility that the cladding enhanced the toughness of the structure. 
would produce a level of stress intensity factor in the dynamically moving flaw in between those obtained in $\mathrm{CP}-3,-8$, and -9 (which arrested more or less within the scatter band for the base plate), and that obtained in $\mathrm{Cr}-5$ (which did not arrest at all). However, such tests were not performed in this series of experiments. It was not possible to reach a level of load that was high enough to produce the required initial conditions as a result of premature pop-ins during loading, such as occurred in $\mathrm{CP}-3$, and $\mathrm{CP}-8$. This was caused by not removing all the stainless steel weld metal prior to EB welding. Mixing of the stainless steel with the low alloy base plate resulted in cracks within the weld nugget, which initiated the low load pop-ins. Specimen CP-5, which did reach the target load of inciplent surface ylelding and demonstrated that rapid fracture in the presence of moderately tough cladding could occur, produced a valuable upper limit at which arrest did not happen.

Removing all traces of the cladding prior to EB welding, as in specimen $\mathrm{CP}-9$, solved the problem of premature pop-ins. However, the resulting deep groove geometry introduced sufficient experimental and analytical ambiguities that no improvement in defining the structural effect of the cladding on composite crack-arrest properties of the clad-plate specimens was obtained.

CONCLUSIONS - PHASE ONE

By comparing the behavior of type $308 / 309$ stainless steel clad plates $\mathrm{CP}-3$, $\mathrm{CP}-5, \mathrm{CP}-8$, and $\mathrm{CP}-9$ with that of the unclad plate and the base plate crack-arrest data, it appears that moderately low-toughness stainless steel cladding has a limited capacity to arrest a runing flaw on the surface and keep a short flaw from becoming long. One specimen arrested at a calculated stress intensity factor in excess of the observed scatter band for crack 
arrest data within the base plate; moreover, none of the flaws that arrested should have done so in the existing stress field unless there had been some degree of pinning of the ends of the flaw by a tough surface layer. It is important to stress, however, than any structural toughness enhancement by the cladding in this study was 11mited. The fact that plate CP-5 fractured completely with no Indication of cladding-induced arrest is a clear demonstration of the moderately tough cladding's limitation.

PLANS FOR CLAD PLATE EXPERIMENTS - PHASE TWO

Phase two of the clad plate experiments will better define the structural effects of cladding, using both enhanced experimental technique and high quality commerclally produced clad overlay weldment.

To eliminate the complications of the groove-induced stress concentration and of having the flaw in a previously welded region, a new spectmen design (Fig. 23) has been used to continue this work in the next series of experiments. In this specimen, prior to welding, the base metal was recessed to a depth equal to that of the cladding on both sides of the middle region. These recessed regions were then filled in with weld cladding. This design provides a flat surface, free from discontinuities, other than the flaw 1tself, for analytical simplicity and will also provide an area not contaminated with stainless steel weld metal in which the EB weld can be placed. This should allow the specimen to reach whatever initial loading conditions are derired to accurately assess the effects of the cladding.

The weldments from which these speclmens have been fabricated were commercially produced using the same three wire series arc procedures employed for the second phase of the cladding irradiation experiments. Only one layer 
Fig. 23. Specimen dimensions and load locations of optimized specimen to be used in Phase Two of clad plate investigations.

of cladding was necessary to meet the thickness requirements for the test plates, whereas three layers were applied to produce an adequate thickness for the companion characterization specimens. However, demanding controls on the finished weldment including subsize impact specimen testing and chemical and metallographic analysis of each layer has assured uniformity among layers of cladding. Specialized heat treatment of the A 533 grade B chenistry base plate used in fabricating the plates was used to greatly elevate its ductile to brittle transition temperature. The resulting specimens, composed of a highly unfíoru cladding, typical of older reactor pressure vessels deposited on a high transition base plate, will allow the structural evaluation of an arbitrarily tough cladding. Selection of a test temperature between $-25^{\circ} \mathrm{C}$ and $25^{\circ}$ will result in a cladding with charpy impact energy varying from about 40 to $70 \mathrm{~J}$, wille malntaining a fragile base plate (Fig. 24). 


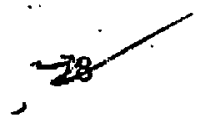

ORNL-DWG 83-4564 ETO

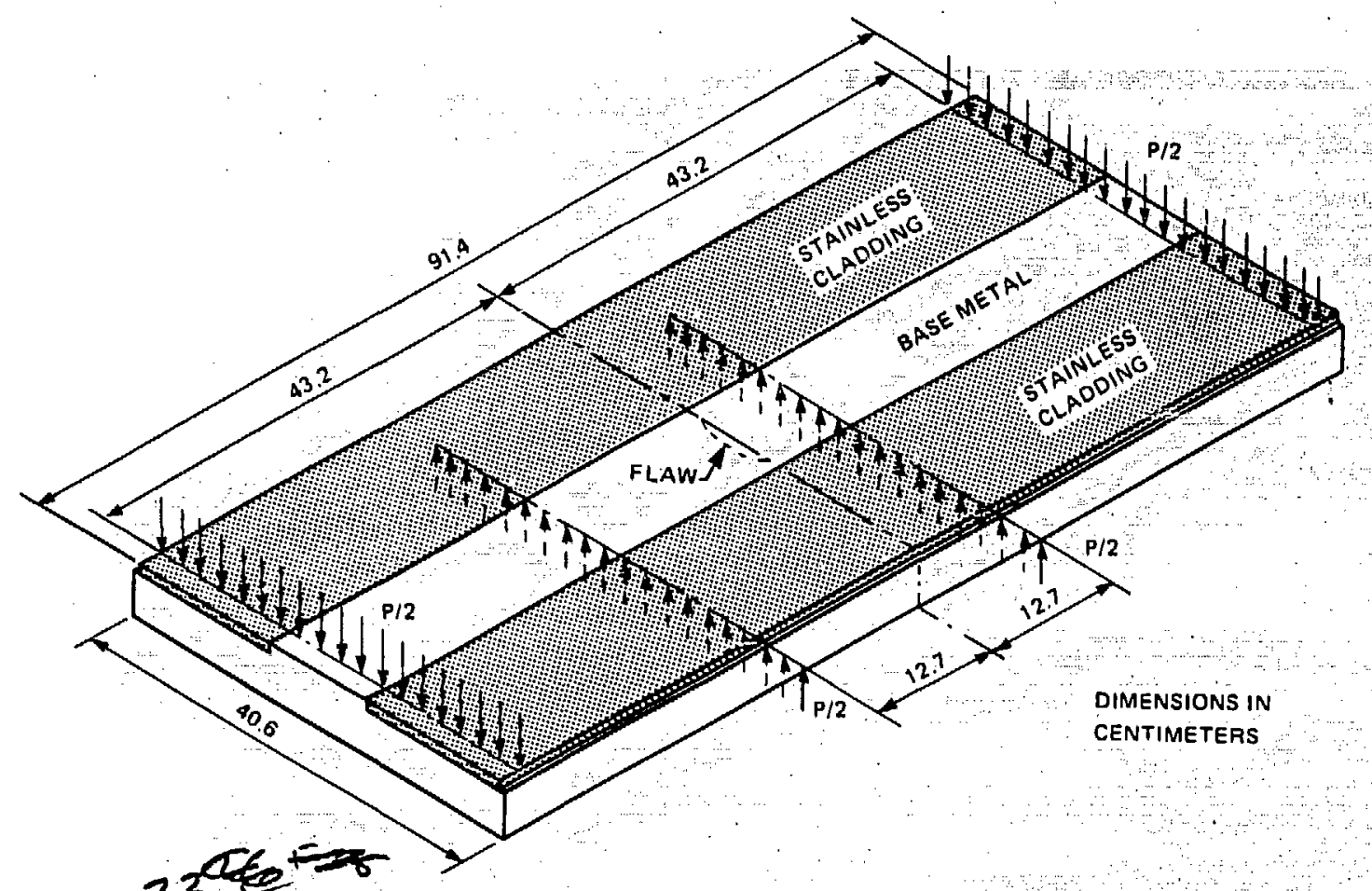

Fig. 4.28. Specimen dimensions and load locations of optimized specimen to be used in Phase Two of clad plate investigations. 
Fig. 24. A clad plate test temperature can be selected for phase two. which will yleld a brittle base plate and an arbltrarlly tough cladding.

In addition to examining the effects of sladding on crack arrest in the composite structure, initiation effects will also be examined. Following popIn and arrest in these specimens, they will be heat tinted to mark the initial fracture surface and then monotonically loaded to failure at a preselected temperature.

All test materials and specimens are currently on hand and materials characterization testing is underway. Plate testing is expected to be completed in 1986.

\section{SUMMARY}

In the two pronged effort on the potential affects of cladding relating to the integrity of an RPV during an over cooling transient, encouraging results were produced. Good quality weld overlay cladding generally maintained its inherent toughness following irradiation exposure and cladding of even only moderate toughness appeared to slightly enhance the integrity of a structural member. Additional irradiation and structural data on a commercial 


\subsection{9 .24}

$\because$

SPECIAL FABRICATION METHODS PRODUCED BEAMS WITH SELECTABLY

TOUGH CJADDING AND BRITTLE BASE METAL

$-37$

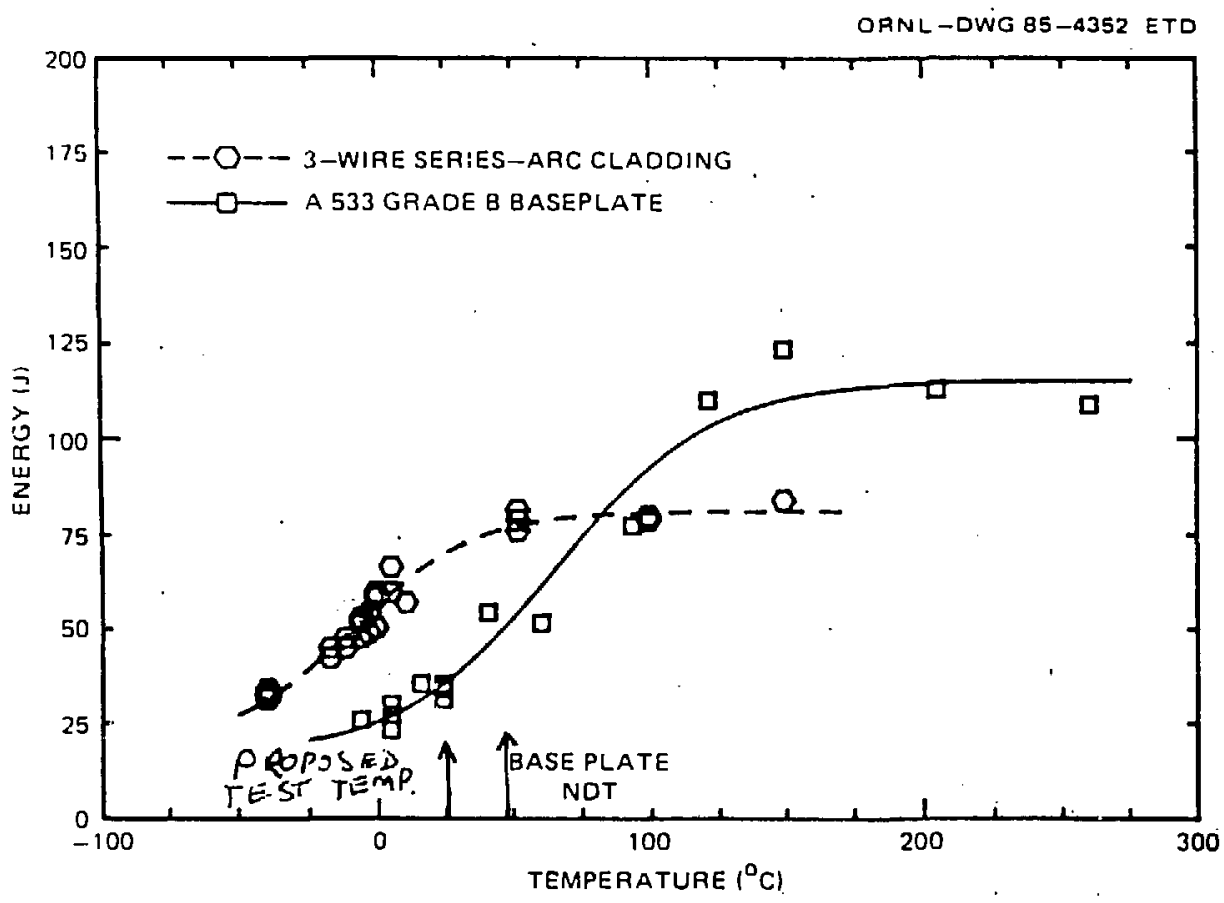


weld overlay being generated in phase two of these experiments will add greatly to the existing understanding of claddir, affects. On the cautionary side, it is clear that poor quality cladding can exhibit marked radiation Induced embrittlement. Moreover, there are clearly loading conditions which negate the limited structural benefit weld overlay can add to a structure.

\section{ACKNOWLEDGMENTS}

The author gratefully acknowledges G. C. Robinson, R. G. Berggren, : and R. K. Nanstad for assistance in designing and executing the experiments, W. J. Stelzman, G. M. Goodwin, J. W. Hendrix, and J. D. Hudson for development of welding and heat-treating procedures and production of the test materials; R. J. Gray and C. P. Haltom for metallographic studies; J. G. Merkle, R. H. Bryan and B. R. Bass for fracture-mechanics analysis; P. P. Holz for electronbeam welding; W. F. Jackson and R. Smlth for instrumentation; R. L. Swain and T. D. Owings for experimental assistance; and D. L. Northern for preparing and revising the manuscript.

\section{REFERENCES}

1. W. R. Corwin, R. G. Berggren, and R. K. Nanstad, Charpy Toughness and Tensile Properties of a Neutron-Irradiated Stainless Steel Submerged Arc Weld Cladding Overlay, NUREG/CR-3927, ORNL/TM-9309, Martin Marietta Energy Systems, Inc., Oak Ridge National Laboratory, September 1984.

2. W. R. Corwin et al., Effect of Stainless Steel Weld Overlay Cladding on the Structural Integrity of Flawed Steel Plates in Bending, Series 1, NUREG/CR-4015, ORNL/TM-9390, Martin Marietta Energy Systems, Inc., Oak Ridge National Laboratory, Apri1 1985.

3. A. Schaeffler, "A Constitution Diagram for Stainless Steel Weld Metal," Met. Prog., 56(5), 1949, 680-680в. 
4. R. J. Gray, "Magnetic Etching with Ferrofluid," Metallographic Specimen Preparation, pp. 155-77, ed. J. L. McCall and W. M. Mueller, Plenum, New York, 1974.

5. E. B. Norris, D. R. Ireland, and C. E. Lautzenhelser, The Second Inspection of the Elk River Reactor Pressure Vessel After Operation, SWRI 1228P9-13, Southwest Research Institute, San Antonio, Tex., July 21, 1967.

6. T. Kondo, H. Nakajima, and R. Nagasaki, "Metallographic Investigation on the Cladding Fallure in the Pressure Vessel of a BWR," Nuci. Eng. Des. 16, 205-22 (1971).

7. D. T. read et al., "Metallurgical Factors Affecting the Toughness.of 316L SMA Weldments at Cryogentc Temperatures," Weld J. 59(4), 104-113-s (April 1980).

8. F. W. Bennett and C. P. Dillon, "Impact Strength of Austenitic Stainless Steel Welds at $-320^{\circ} \mathrm{F}$ - Effects of Composition, Ferrite Content, and Heat Treatment," J. Basic Eng. 88, 33-36 (March 1966).

9. G. M. Goodwin, Fracture Toughness of Austenitic Stainless Steel Weid Metal at $4 \mathrm{~K}$, ORNL/TM-9172, Martin Marietta Energy Systems, Inc., Oak Ridge National Laboratory, August 1984.

10. J. R. Hawthorne and H. E. Watson, "Exploration of the Influence of Welding Variables on Notch Ductility of Irradiated Austenitic Stainless Steel Welds," Proc. Int. Conf". On Radiation Effects in Breeder Reactor Structural Materials, pp. 327-36, Scottsdale, AZ, June 1977.

11. W. R. Corwin, Assessment of Radiation Effects Relating to Reactor Pressure Vessel Cladding, NUREG/CR-3671 (ORNL-6047), Martin Marietta Energy Systems, Inc., Oak Ridge National Laboratory, July 1984. 
12. J. G. Merkle, "Stress-Intensity Factor Estimates for Part-Through Surface Cracks in Plates Under Combined Tension and Bending," pp. 3-22 in Quarterly Erogress Report on Reactor Safety Programs Sponsored by the Division of Reactor Safety Research for July-September 1974, ORNL/TM-4729, Vol. II, Union Carbide Corporation, Nuclear Division, Oak Ridge National Laboratory.

13. R. D. Cheverton et al., Applicability of LEFM to the Analysis of PWR Vessels Under LOCA-ECC Thermal Shock Conditions, NUREG/CR-0107 (ORNL/NUREG-40), Union Carbide Corporation, Nuclear Division, Oak Ridge: National Laboratory, October 1978.

14. J. C. Newman, Jr., and I. S. Raju, Analyses of Surface Cracks in Finite Plates Under Tension or Bending Loads, NASA Technical Paper 1578, 1979.

15. B. R. Bass and J. W. Bryson, ORVIRT: A Finite Element Program for Energy Release Rate Calculations for 2-Dimensional and 3-Dimensional Crack Models, NUREG/CR-2997, Vo1. 2 (ORNL/TM-8527/V2), Union Carbide Corporation, Nuclear Division, Oak Ridge National Laboratory, February 1983. 